\title{
Voltage-Gated Sodium Channels: A Prominent Target of Marine Toxins
}

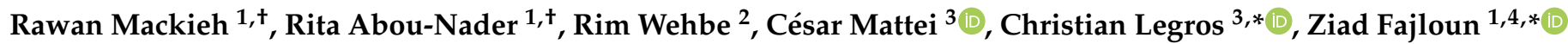 \\ and Jean Marc Sabatier $5, *$ (D)
}

1 Faculty of Sciences 3, Department of Biology, Lebanese University, Campus Michel Slayman Ras Maska, Tripoli 1352, Lebanon; rawan97mck@gmail.com (R.M.); ritaabounaderr@hotmail.com (R.A.-N.)

2 Biology Department, Faculty of Arts and Sciences, American University of Beirut, Beirut 1107 2020, Lebanon; rgw00@mail.aub.edu

3 University of Angers, INSERM U1083, CNRS UMR 6015, MITOVASC, SFR ICAT, 49000 Angers, France; cesar.mattei@univ-angers.fr

4 Laboratory of Applied Biotechnology (LBA3B), Azm Center for Research in Biotechnology and Its Applications, Doctoral School of Sciences and Technology (EDST), Lebanese University, Tripoli 1300, Lebanon

5 The Institute of NeuroPhysiopathology (INP), Aix-Marseille Université, CNRS, INP, 13385 Marseille, France

* Correspondence: christian.legros@univ-angers.fr (C.L.); ziad.fajloun@ul.edu.lb (Z.F.); sabatier.jm1@gmail.com (J.M.S.)

+ Equal contribution.

check for updates

Citation: Mackieh, R.; Abou-Nader, R.; Wehbe, R.; Mattei, C.; Legros, C.; Fajloun, Z.; Sabatier, J.M. Voltage-Gated Sodium Channels: A Prominent Target of Marine Toxins. Mar. Drugs 2021, 19, 562. https:// doi.org/10.3390/md19100562

Academic Editor: Marialuisa Menna

Received: 8 September 2021

Accepted: 2 October 2021

Published: 5 October 2021

Publisher's Note: MDPI stays neutral with regard to jurisdictional claims in published maps and institutional affiliations.

Copyright: (c) 2021 by the authors. Licensee MDPI, Basel, Switzerland. This article is an open access article distributed under the terms and conditions of the Creative Commons Attribution (CC BY) license (https:// creativecommons.org/licenses/by/ $4.0 /)$.

\begin{abstract}
Voltage-gated sodium channels (VGSCs) are considered to be one of the most important ion channels given their remarkable physiological role. VGSCs constitute a family of large transmembrane proteins that allow transmission, generation, and propagation of action potentials. This occurs by conducting $\mathrm{Na}^{+}$ions through the membrane, supporting cell excitability and communication signals in various systems. As a result, a wide range of coordination and physiological functions, from locomotion to cognition, can be accomplished. Drugs that target and alter the molecular mechanism of VGSCs' function have highly contributed to the discovery and perception of the function and the structure of this channel. Among those drugs are various marine toxins produced by harmful microorganisms or venomous animals. These toxins have played a key role in understanding the mode of action of VGSCs and in mapping their various allosteric binding sites. Furthermore, marine toxins appear to be an emerging source of therapeutic tools that can relieve pain or treat VGSC-related human channelopathies. Several studies documented the effect of marine toxins on VGSCs as well as their pharmaceutical applications, but none of them underlined the principal marine toxins and their effect on VGSCs. Therefore, this review aims to highlight the neurotoxins produced by marine animals such as pufferfish, shellfish, sea anemone, and cone snail that are active on VGSCs and discuss their pharmaceutical values.
\end{abstract}

Keywords: VGSCs; marine toxins; neurotoxins; pufferfish; shellfish; sea anemone; cone snail

\section{Introduction}

Voltage-gated sodium channels (VGSCs) have been the topic of significant research and discussion for a considerable amount of time given their unique functions in electrical cell signaling. In 1952, Hodgkin and Huxley were the first to establish the existence of VGSCs and their crucial role in the generation of action potentials (APs) for which they won the Nobel Prize in 1963 [1,2]. VSGCs are activated by membrane depolarization, resulting in a fast and temporary $\mathrm{Na}^{+}$influx before an intracellular loop quickly closes the pore [3]. These channels are very important for homeostasis, thus some genetic abnormalities in VGSC genes can result in a varied range of disorders known as "channelopathies" [4] such as muscle, cardiac, and neurological disorders [5]. Moreover, because of their ability to bind local anesthetics, VGSCs are the major target to treat different types of pain [6]. These 
ion channels are pharmacologically validated molecular targets for a large panel of clinically used drugs, such as antiarrhythmics, anticonvulsants, anesthetics, and analgesics [7]. Researchers have studied many pharmacological agents, including marine neurotoxins, to develop treatments for VGSC-related disorders and pain-relieving drugs. Neurotoxins produced by marine animals or microorganisms can bind to VGSCs at different sites, resulting in either activation or inhibition of the channel [2]. These toxins such as tetrodotoxin (TTX) and saxitoxin (STX), two pore-blocking toxins, have significantly improved our comprehension of the VGSCs function and structure [8]. Hence, this review aims to provide an overview of the main toxins produced by venomous marine animals and microorganisms that act on VGSCs and examine their pharmaceutical potential in the management of pain and some diseases.

\section{Voltage-Gated Sodium Channel (VGSC) Structure}

VGSCs are important members of the voltage-gated ion channel superfamily. These channels are known to transport ions between extra- and intracellular compartments in a voltage-dependent manner [9]. The initiation and propagation of APs in excitable cells are due to the presence of VGSCs, which allows $\mathrm{Na}^{+}$influx. They also play an important role in non-excitable cells, such as T-lymphocytes, macrophages, endothelial cells, and astrocytes including $\mathrm{Na}(+) / \mathrm{K}(+)$-ATPase activity, as well as in regulation of effector functions such as phagocytosis metastatic activity and motility [10]. VGSC is a large protein constituted of two or three subunits: $\alpha(260 \mathrm{kDa})$ pore-forming subunit, which is linked to one or two $\beta 1-4$ auxiliary subunits (30-40 kDa) [11]. The $\alpha$ subunit by itself is enough for the functional expression of the channel. However, the auxiliary $\beta$ subunits are needed for the localization of the channel as well as its interaction with cell adhesion molecules, intracellular cytoskeleton, and extracellular matrix. $\beta$ subunits are also crucial for the modification of the kinetics and voltage dependency of the channel's gating [12]. $\alpha$ subunits contain four homologous, but not identical, domains (I-IV) in tandem. Each domain has six transmembrane helixes (S1-S6) and a pore-forming loop between the S5 and S6 segments [12,13] (Figure 1). Every third position in the S4 segments of each domain contains positively charged amino acid residues. These residues operate as gating charges, moving across the membrane to activate channels in response to membrane depolarization [12]. Subsequently, $\mathrm{Na}^{+}$ions move under the influence of the transmembrane electrochemical gradient, leading to membrane depolarization, throughout the expanding phase of an action potential [13]. Regarding the inactivation gate, a small intracellular loop connecting the two homologous domains III and IV that folds into the channel structure is responsible for the blockage of the pore from the inside during sustained membrane depolarization [12]. Thus far, nine mammalian subunit isoforms have been discovered, resulting in nine VGSC subtypes (NaV1.1-NaV1.9) encoded by distinct genes [7]. Furthermore, the $\alpha$ subunit provides a binding site for a wide range of drugs such as antiarrhythmic, anti-epileptic, and local anesthetics, as well as various neurotoxins that target VGSC and can significantly change the channel's activity [14]. 


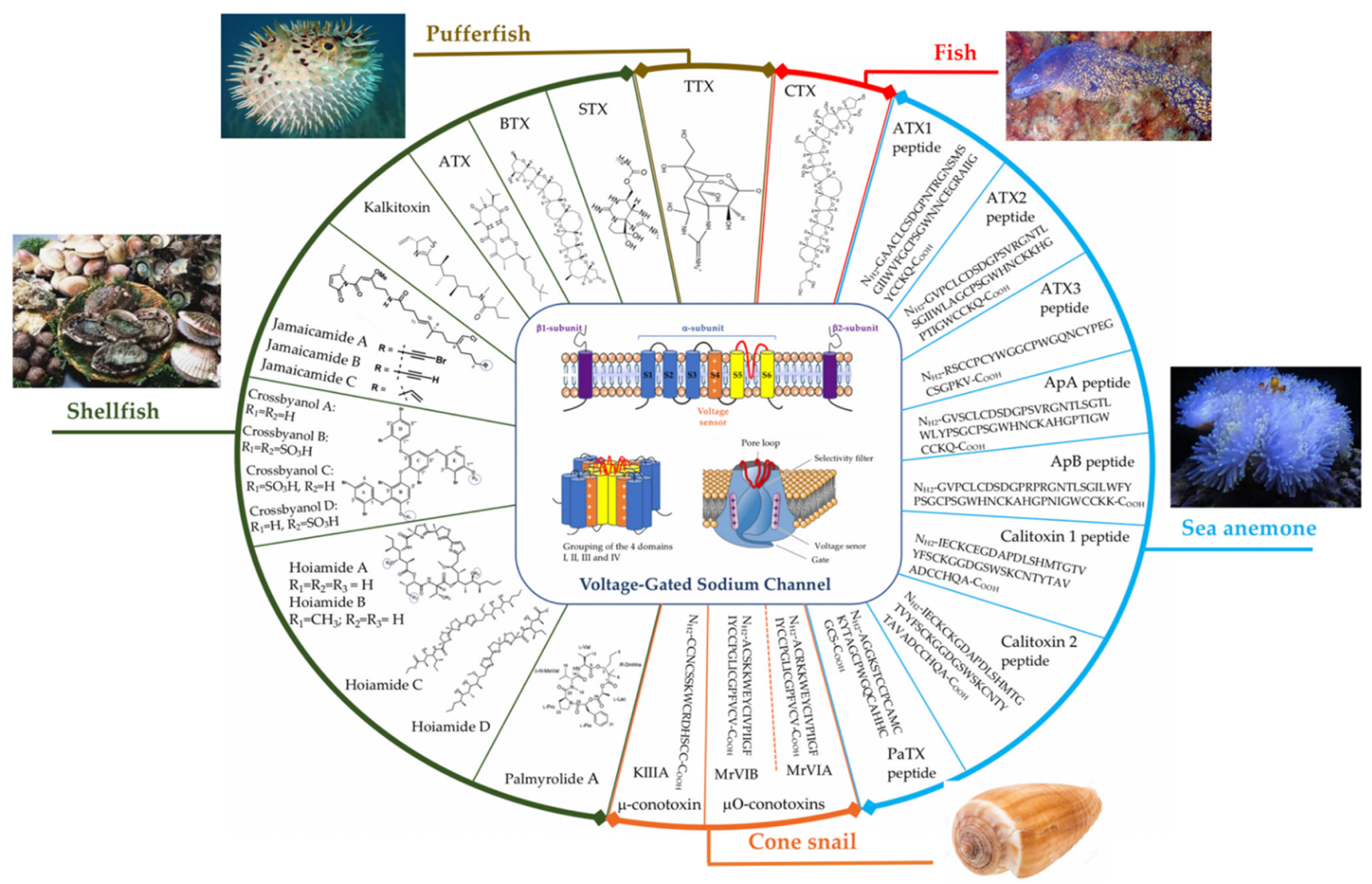

Figure 1. In the middle: overview of the VGSC structure including the different subunits: $\alpha, \beta 1$, and $\beta 2$ (only one domain of the polypeptide is shown, in the top), as well as the selective pore formed by these subunits (at the bottom), and the main toxins present in marine animals that are active on these channels, as well as their identified chemical structures (peptide and non-peptide).

\section{Toxins from Marin Animals That Target VGSCs}

\subsection{From Fish}

\subsubsection{Tetrodotoxin (TTX)}

The neurotoxin, tetrodotoxin (TTX), is found in marine species, particularly in pufferfish. Marine species do not produce TTX by themselves, they rely on the presence of toxin-synthetizing bacteria (i.e., Pseudoalteromonas, Pseudomonas, Vibrio, Aeromonas, Actinomycetes, Microbacterium, Serratia, etc.) to produce the neurotoxin. These bacteria are either part of the animal's microbiome or can bioaccumulate through the food chain [15]. The chemical formula of TTX is $\mathrm{C}_{11} \mathrm{H}_{17} \mathrm{~N}_{3} \mathrm{O}_{8}$, and it contains a guanidinium group. TTX is water-soluble and stable in strong acidic solutions only [16]. It is highly toxic on the animal's physiology. It suppresses almost any function that is dependent on the nerve and muscle, as well as the cell's excitability. TTX has been used for years to study and identify the structure and function of VGSCs. Additionally, TTX exclusively blocks these channels when applied to the neuronal membrane's exterior surface by binding to the toxin's site 1 of $\alpha$-subunit. However, when applied intracellularly, even at concentrations as high as 1 $\mu \mathrm{M}$, it has no effects on the channel $[16,17]$. Also, Chen et al. have recently elucidated the mechanism of blocking VGSCs by TTX. They found that TTX blocks NaV1.4 via creating a network of hydrogen bonds (H-bonds) with the outer charged ring. Furthermore, the guanidinium group of TTX maintains a lateral orientation relative to the filter on blocking NaV1.4. The acidic residues on the outer membrane are essential for the stabilization of the H-bonds [18]. The guanidine groups in TTX are positively charged, while the residues, Glu755 and Asp400 in domain II and I of the channel, are negatively charged, resulting in the creation of a strong interaction. In addition, the guanidinium group is a relatively large 
molecule, making it difficult for TTX to penetrate through the channel. Consequently, the $\mathrm{Na}^{+}$ion route becomes clogged and causes the blocking of the channel that inhibits the transmission of Aps impulses and results in loss of excitability and paralysis [8,19-22].

VGSCs are separated into two classes depending on their sensitivity to TTX: TTXresistant (TTX-R), which needs concentrations in the micromolar range to efficiently be blocked by TTX, and TTX-sensitive (TTX-S), for which only nanomolars of TTX are sufficient to block them. Among the known TTX-S VGSCs, there are NaV1.1, NaV1.2, NaV1.3, NaV1.4, NaV1.6, and NaV1.7 subtypes. NaV1.5, NaV1.8, and NaV1.9 subtypes are TTX-R VGSCs (12). This selectivity of action makes TTX an important pain blocker agent; NaV 1.5, which is mainly expressed in the heart, is grouped under TTX-R class.

Given the critical role of VGSCs in pain signaling, TTX has become prominent as a therapeutic candidate for pain [23]. Several studies have verified the effect of TTX in inflammatory pain. When carrageenan, a pro-inflammatory drug, was administrated with TTX, mechanical and thermal hyperalgesia were reduced throughout the inflammatory response in rats [24]. Another study showed that TTX reduced thermal hypersensitivity in rats suffering from chronic inflammatory pain. Moreover, in the same study, when the inhibitory effect of TTX was compared with carbamazepine, an inhibitor of the voltagegated sodium channel, it was found that the effect of TTX was 150 times greater than carbamazepine [25]. Earlier studies have demonstrated that, apart from inflammatory pain, TTX exerts an effect on acute pain [26-28]. Moreover, Marcil et al. have shown that TTX reduces visceral and neuropathic pain in Wistar rats, with no documented side effects to date, whereas morphine was shown to cause heavy sedation [29]. The previously mentioned results are compatible with the results of González-Cano et al., who demonstrated that blocking TTX-S sodium channels, but not NaV 1.7 alone (Figure 2), by TTX could be an effective treatment for visceral pain in viscero-specific mouse models [30].

A

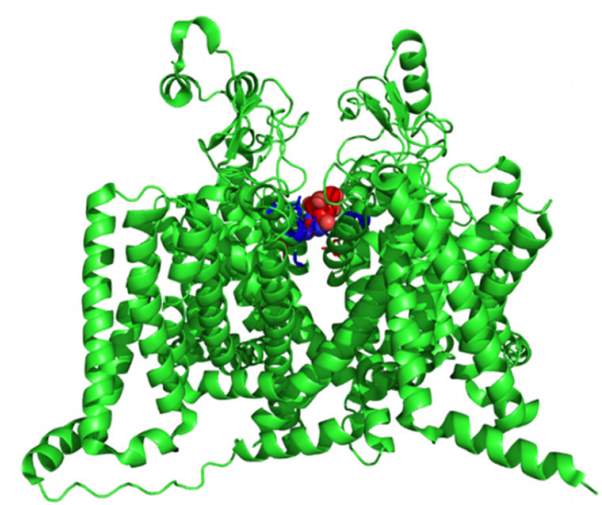

B

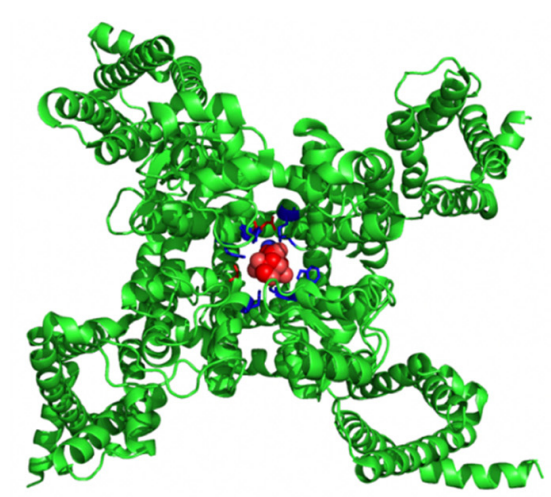

C

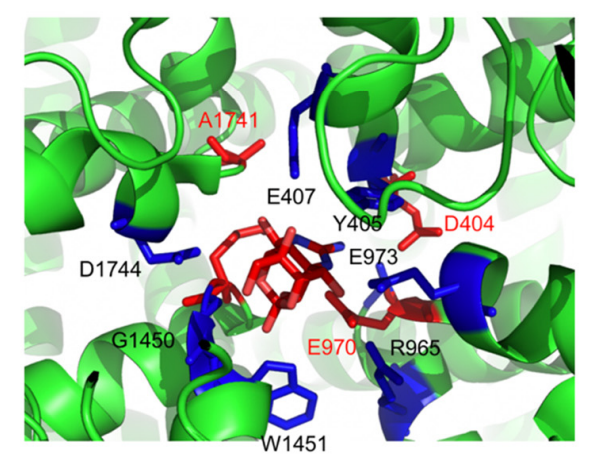

Figure 2. Interaction of TTX with Nav1.7 channel. Docking model of TTX-Nav1.7 channel interaction resolved by CryoEM (pdb code 6J8I, [31]). Nav1.7 channel is displayed as a cartoon, while TTX is shown 
as spheres. (A) Profile view; (B) top view. (C) Close-up showing the TTX-binding site within the pore. Lateral chains of amino acids interacting with TTX are labeled. In red are the amino acids that form the selective filter (DEKA). TTX is shown in the center of the pore in stick. The figures were prepared with PyMOL (DeLano W.L. (2010) The PyMOL Molecular Graphics System, version 1.6, Schrodinger, LLC, New York, NY, USA).

TTX has been proven to be most efficient in neuropathic pains, particularly against cancer-related pain with tolerable toxicity and long-term safety [32,33]. Clinical studies have demonstrated that subcutaneous or intramuscular local injection of TTX is beneficial to treat cancer pain [32,34]. According to a recent study, in chemotherapy-induced neuropathic pain patients, $30 \mathrm{~g}$ BID of TTX given for 4 days every 3 weeks produced analgesia [35]. Moreover, when compared to TTX intramuscular injection, TTX pellets significantly improved safety in rats suffering from postherpetic neuralgia [36]. Furthermore, TTX-treated paclitaxel induced neuropathic pain in mice by reducing mechanical cold allodynia, and the development of thermal hyperalgesia [37]. The effect of TTX on burn-related pain has also been tested. Normally, opioids are used to treat the pain caused by burn injuries. However, due to the opioids' negative side effects [38], TTX is considered a suitable alternative. Salas et al. suggested that systemic TTX could be used as a valuable rapid acting analgesic for burn injuries and could replace or reduce the use of opioid analgesics [39]. In addition, TTX has the potential to reduce thermal hyperalgesia and mechanical allodynia [39,40]. Pain-induced neurogenesis was greatly decreased when TTX was delivered locally and persistently to the sciatic nerve trunk [41]. Moreover, it has been demonstrated that a small dose of TTX reduces cue-induced increases in heroin and the associated anxiety [42].

Concerning the safety of TTX, a recent study examined the therapeutic dosages of TTX that could be administrated. The findings showed that all doses have an acceptable tolerability and PK profiles. Additionally, all doses demonstrated an absence of any clinically significant toxicity. Up to $45 \mu \mathrm{g}$ of TTX was found safe and tolerated in terms of cardiac safety [43]. Like any other toxin, TTX may present some limitations such as the low efficacy of diffusion through diverse tissue barriers to the site of action, which means that the blockage of $\mathrm{NaV}$ will also be limited [44]. To surpass these difficulties and accomplish adequate amounts and duration of nerve fibers to create a blocking effect, high concentrations of the toxin are needed. This can result in considerable systemic toxicity. To improve the penetration and the analgesic signal, many studies have worked on coupling TTX with other compounds called chemical permeation enhancers reviewed before $[45,46]$. Moreover, epinephrine and bupivacaine have been previously used to improve the efficacy of TTX and prolong the analgesic effect $[47,48]$. Moreover, Santamaria et al. have proved that the negative side effects linked to the toxicity of TTX were remarkably reduced with epinephrine and yielded even greater results than with chemical permeation enhancers (CPEs), which are known to improve nerve blockage caused by site 1 sodium channel blockers such as TTX [49]. Finally, when TTX was combined with capsaicin, a component found in chili pepper that can cause sensory-selective peripheral nerve blockage, prolonged duration of local anesthesia was detected [50].

\subsubsection{Ciguatoxins (CTXs)}

CTXs are lipophilic cyclic polyethers with more than 20 analogues that have been described thus far. They are synthesized by benthic dinoflagellates of the genius Gambierdiscus [51]. These toxins can contaminate the food chain from the dead coral reef, which is colonized by dinoflagellates, consumed by herbivorous fish that are themselves the prey of carnivorous fish. Fish carrying CTXs can store these toxins without being affected by their harmful effects. CTXs are heat-resistant and do not alter the organoleptic properties of the contaminated fish. In humans, CTXs are responsible for a complex human food syndrome called ciguatera, characterized by peripheral neurological symptoms (myalgias, cold allodynia, arthralgias, paresthesia, pruritus) and central symptoms (ataxia, headache) [52,53]. Cardiovascular signs-bradycardia and low blood pressure-and gastrointestinal signs—abdominal pain, 
vomiting, nausea-are also observed. All these symptoms persist for several days, and in most cases disappear spontaneously. There is no specific treatment for ciguatera, and the treatment is purely symptomatic [53]. The symptoms observed are like those described in neurotoxic shellfish poisoning (see Section 3.2.2.)

CTXs act like brevetoxins (BTXs) by binding to site 5 of $\mathrm{NaV}$ channels at the intracellular segments 6 and 5 of domains I and IV, respectively [54,55]. Their mode of action is therefore similar: they slow down the inactivation of the $\mathrm{Na}^{+}$current, which facilitates the persistent entry of $\mathrm{Na}^{+}$into the cells. They also shift the activation of the $\mathrm{Na}^{+}$current towards more negative potentials [56,57]. These toxins are therefore activators of $\mathrm{NaV}$ channels. The result is the generation of repetitive action potentials, characteristic of the exacerbated excitability, which is at the origin of the symptoms observed in humans [58]. Ciguatera is a disease present in the Pacific Ocean, the Indian Ocean, and the Caribbean area.

\subsection{From Shellfish}

\subsubsection{Saxitoxin (STX)}

STX is a non-peptide neurotoxin found in shellfish and produced by marine dinoflagellates that accumulate in shellfish via the food chain. Three species of dinoflagellate, Alexandrium, Pyrodinium, and Gymnodinium, are responsible for STX production in the marine environment [59]. STX is known as a "paralytic shellfish toxin" (PST) since it is responsible of a food intoxication called "paralytic shellfish poisoning" (PSP) syndrome [8,60]. The molecular formula of STX is $\mathrm{C}_{10} \mathrm{H}_{17} \mathrm{~N}_{7} \mathrm{O}_{4}$. It is considered as one of the most lethal toxins for humans. Poisoned persons can develop symptoms within 30 minutes beginning with a burning or tingling sensation on the lips and face and progressing to total numbness that may expand to the fingers and toes and reach the extremities. Other symptoms may include perspiration, vomiting, diarrhea, and stomach cramps. An overdose (toxic dose in humans is 1-4 mg/person) of STX can cause death due to respiratory failure and cardiovascular shock [61,62]. To date, no specific antidotes to STX have been approved. Activated charcoal that remove unabsorbed poisons and artificial respiration are the two frequent treatments used for PSP in its early stages [61].

Aside from TTX, STX is a powerful neurotoxin that preferentially targets VGSCs. The mechanism of binding of STX on VGSCs occurs via binding to the pore-forming region of the alpha-loop VGSC, located between S5 and S6 (Figure 1). This mechanism is similar to that of TTX, as they both belong to guanidinium toxins $[8,63]$. TTX and STX were the primary neurotoxins discovered that bind at site 1 of VGSC [2]. The guanidinium groups confer a positive charge at physiological $\mathrm{pH}$ that will enable the toxin to bind VGSC at site 1. Later, the conductance of $\mathrm{Na}^{+}$through the channel is blocked. STX interferes with the genesis of APs in neurons and skeletal muscle at nanomolar concentrations $[2,8,59]$.

The systematic toxicity caused by STX constitutes a major obstacle for its clinical use as an anesthetic and analgesic agent. In addition, and unlike TTX, STX has been shown to cross the blood-brain barrier. Several studies have worked on developing methods that can reduce STX's toxicity. STX was tested for its effect as an anesthetic agent in rabbit cornea, rat, and dog [64]. When given at high concentration, long term blockage is obtained but a systemic toxicity occurs. To decrease this toxicity, STX was combined with a vasoconstrictor agent. Researchers found that the systemic toxicity was reduced while the frequency of adequate blocks and their mean duration were enhanced [64]. Another study has demonstrated that STX acts as an efficient, safe, and long-term corneal anesthetic in rabbits after mechanical corneal abrasion and photorefractive keratectomy [65]. Site 1 blockers are found to prolong nerve blockade. Studies showed that the combination of tricyclic antidepressants, known for their role as local anesthetics, with STX prolonged the duration of local anesthesia [66]. Similarly, the co-administration of STX with dexmedetomidine, an $\alpha 2$-adrenergic receptor agonist, has expanded the analgesic effect in cornea without causing retardation in corneal wound healing. As a result, such combination can be effective in managing acute surgical and nonsurgical corneal pain [67]. Researchers have developed 
liposomal formulations containing a mixture of STX, bupivacaine, a local anesthetic that blocks the $\alpha$ subunit of VGSC, and dexamethasone as an inflammation reliever. The formed mixture has provided long-lasting local anesthetic effect with low systemic toxicity and caused sciatic nerve blockade in male Sprague-Dawley rats that lasted for up to 7.5 days. Systematic toxicity was only observed with high doses of dexamethasone that has boosted the release of liposomal STX. Formulations that only contain bupivacaine showed mild myotoxicity. Thus, regulated release of STX can provide long-term nerve blockade with low systemic and local toxicity [68].

STX possesses more than 50 natural analogues that block $\mathrm{NaV}$ in the same way that STX does, such as neosaxitoxin (neoSTX), decarbamoylsaxitoxin (dcSTX), and gonyautoxins I-III $[69,70]$. One of these analogues, ST-2530, was evaluated against human NaV1.7, which is involved in pain transmission. Results showed that pharmacologic blockage of NaV1.7 by a small-sized molecule agent with affinity for the channel's resting state is sufficient for the production of an analgesic effect in a variety of preclinical pain models [70]. NeoSTX presents a low risk of side effects and might be used as a long-term local anesthetic [71-74]. Moreover, NeoSTX has been tested for its analgesic effect in piglet castration and was proven to be an effective and safe pain reliever [75]. Moreover, it has been demonstrated that NeoSTX is a long-acting local pain blocker used to treat patients suffering from bladder pain syndrome. NeoSTX exerts an analgesic effect in patients going through laparoscopic cholecystectomy [76,77]. Moreover, NeoSTX is considered to be a beneficial tool that reversibly inactivates various brain regions for an extended duration of time with low diffusion and without being harmful to neurons. Furthermore, NeoSTX can be suitable as a VGSC inhibitor in a variety of in vivo studies as well as for prospective therapeutic applications [78]. Gonyautoxin, one of STX analogs, has the potential to safely inhibit neural transmission of pain during knee arthroplasty and chronic tension-type headache $[79,80]$.

\subsubsection{Brevetoxins (BTXs)}

BTXs are lipid soluble neurotoxins found in shellfish and produced essentially by the dinoflagellate Kerenia brevis. BTXs can also be produced by other species such as K. selliformis, K. papilionacea, K. mikimotoi, K. brevisulcata, Chatonella antiqua, Fibrocapsa japonica, and Heterosigma akashiwo [81,82]. BTXs are a type of polyether neurotoxin with a ladder frame structure and two different types of backbone structures. Type 1: BTX-2, 3, 5, 6, 8, and 9 (brevetoxin B backbone) and type 2: BTX-1, 7, and 10 (brevetoxin A backbone). Notably, all BTXs can be considered as derivates of the BTX-1 and BTX-2 [2]. The most common symptoms of severe poisoning with BTXs are headache, gastroenteritis, diarrhea, nausea, sensory problems, cranial nerve dysfunction, scorching sensation in the rectum, bradycardia, ataxia, paresthesia, and ataxia. BTXs can also lead to a condition known as respiratory irritation syndrome [82-85]. BTX has been shown to bind to VGSCs, particularly to TTX-S VGSCs, interacting with $\alpha$-subunit at site 5 . This results in the inhibition of inactivation of VGSC while also shifting activation to more negative membrane potentials, causing conformational variation that leads to atypical channel opening and $\mathrm{Na}^{+}$ current increase [81,86-88]. Other studies identified S6 of DI and S5 of DIV to be involved in the development of neurotoxic receptor 5, using a photoreactive BTX-3 derivate as a probe [89]. BTXs are the only VGSC modifying toxins known to have the ability to stabilize multiple conductance levels [2]. A recent study has demonstrated that BTX-2 improved synapse density and dendritic arborization and of cortical layer $\mathrm{V}$ pyramidal neurons in the peri-infarct cortex in mice after a photothrombotic stroke. In addition, BTX-2 resulted in a significant amelioration in motor recovery [90].

\subsubsection{Antillatoxin (ATX)}

ATX is a cyclic lipopeptide produced from pantropical marine cyanobacterium Lyngbya majuscule [91]. A cutaneous exposure to L. majuscula can cause dermatitis with burning sensations. ATX possesses neurotoxic effects in initial cultures of rat cerebellar granule cells, with thinning of neuritis, swelling of neuronal somata, blebbing of neurite 
membranes, respiratory irritation, and eye inflammation [92,93]. Co-administration of ATX with noncompetitive antagonists of the N-methyl-d-aspartate (NMDA) receptor such as MK-801 and dextrorphan can prevent the ATX-induced neurotoxicity. Additionally, TTX inhibits ATX's effects [94,95]. It has been demonstrated that the lipopeptide ATX acts as a VGSC activator and interacts with its $\alpha$-subunit. However, the precise binding site of ATX is still unrecognized $[2,96]$. Cao et al. have demonstrated that in cells heterologously expressing rat $\mathrm{NaV1.2}$, rat $\mathrm{NaV1.4}$, or rat $\mathrm{NaV1.5}$-subunits, ATX was able to enhance $\mathrm{Na}^{+}$ influx. The results proved that the effectiveness of ATX was unique and was not shared before by any VGSC-subunit activators acting at sites 2 and 5. These findings show that ATX is a VGSC activator with distinct pharmacological features. Deciphering ATX's mechanism of action and molecular determinants might provide additional insights into VGSC gating processes [96]. In Table 1, the other, less-documented toxins present in shellfish that are also active on VGSCs are presented.

Table 1. Other toxins from shellfish that target VGSCs.

\begin{tabular}{|c|c|c|c|}
\hline Toxin & Source/Chemical Formula & Mechanism & References \\
\hline Kalkitoxin & Lyngbya majuscule $/ \mathrm{C}_{21} \mathrm{H}_{38} \mathrm{~N}_{2} \mathrm{OS}$ & $\begin{array}{c}\text { VGSCs blocker } \\
\text { (including TTX-S VGSC) }\end{array}$ & {$[59,97,98]$} \\
\hline Jamaicamides A & $\begin{array}{l}\text { Lyngbya majuscule (strain } \\
\text { JHB) } / \mathrm{C}_{27} \mathrm{H}_{37} \mathrm{O}_{4} \mathrm{~N}_{2} \mathrm{ClBr}\end{array}$ & VGSCs blocker & {$[59,99]$} \\
\hline Jamaicamides B & $\begin{array}{l}\text { Lyngby majuscule (strain } \\
\mathrm{JHB}) / \mathrm{C}_{27} \mathrm{H}_{37} \mathrm{O}_{4} \mathrm{~N}_{2} \mathrm{Cl}\end{array}$ & VGSCs blocker & {$[59,99]$} \\
\hline Jamaicamides C & $\begin{array}{l}\text { Lyngby majuscule (strain } \\
\text { JHB) } / \mathrm{C}_{27} \mathrm{H}_{39} \mathrm{O}_{4} \mathrm{~N}_{2} \mathrm{Cl}\end{array}$ & VGSCs blocker & {$[59,99]$} \\
\hline Crossbynols A & Leptolyngbya crossbyana/ $\mathrm{C}_{30} \mathrm{H}_{15}{ }^{79} \mathrm{Br}_{7} \mathrm{O}_{6}$ & VGSCs activator & {$[100]$} \\
\hline Hoiamides A & $\begin{array}{l}\text { Lyngbya majuscula and Phormidium } \\
\text { gracile } / \mathrm{C}_{44} \mathrm{H}_{71} \mathrm{~N}_{5} \mathrm{O}_{10} \mathrm{~S}_{3}\end{array}$ & VGSCs activator at site 2 & {$[59,101]$} \\
\hline Hoiamides B & $\begin{array}{l}\text { Marine cyanobacteria in Papua New } \\
\text { Guinea } / \mathrm{C}_{45} \mathrm{H}_{73} \mathrm{~N}_{5} \mathrm{O}_{10} \mathrm{~S}_{3}\end{array}$ & VGSCs activator at site 2 & {$[59,102]$} \\
\hline Palmyrolide A & $\begin{array}{l}\text { Leptolyngbya cf and Oscillatoria } \\
\text { spp. } / \mathrm{C}_{20} \mathrm{H}_{36} \mathrm{O}_{3} \mathrm{~N}\end{array}$ & VGSCs blocker & [103] \\
\hline Palmyramide A & Cyanobacteria $/ \mathrm{C}_{36} \mathrm{H}_{53} \mathrm{~N}_{3} \mathrm{O}_{9}$ & VGSC blocker & [104] \\
\hline
\end{tabular}

\subsection{Toxins from Sea Anemones}

Sea anemones belong to the Cnidaria phylum. Cnidarians are known to have an uncommon morphological and genetic variety. In fact, all cnidarians have specialized cells, named nematocytes, that comprise a small stinging apparatus known as nematocysts involved in defense and prey capture. These nematocysts enclose a high venom complex produced by nematocytes [105-107]. The venom complex produced by sea anemones contains neurotoxins that target VGSCs $[108,109]$. An intoxication by this toxin complex causes paralysis, pain, necrosis, local itching, erythema, swelling, neurotoxicity, and cardiotoxicity [110]. The cardiotoxicity consists of arrhythmias, produced early after depolarization due to inadequate $\mathrm{NaV}$ channel inactivation, and systolic stop due to $\mathrm{Ca}^{2+}$ ion overloading in myocardial cells [111].

Historically, the first isolated groups of neurotoxins affecting VGSC are ATX I, ATX II, and ATX III isolated from Anemonia viridis and known today as Av1, Av2, and Av3, respectively. Av1 (46 amino acids) and Av2 (47 amino acids) share a high sequence similarity $[112,113]$. This is in contrast to Av3, which has only 27 amino acids and is not related to either Av1 or Av2 in terms of sequence [114] (Figure 1). However, Av3 has been classified in a new different group along with Ea1 (PaTX), a toxin mainly isolated from Entacmaea actinostoloides, since they both lack the fourth disulfide bridge $[115,116]$. Rp1, Rp2, Rp3, 
and Rp4 are other toxins isolated from another species called Heteractis paumotensis and classified as a new group aside from the first group.

Concerning the mechanism by which sea anemone toxins act on VGSCs, it has been demonstrated that they bind to site 3, particularly at the residues in the extracellular loop between S3 and S4 in DIV [2]. In general, a neurotoxin that binds to this site slows down the inactivation process of the channel. This inactivation can be decelerated or even inhibited entirely, and these effects are linked to a slight hyperpolarizing shift in the activation of the channel, since S4 of DIV play a role in the voltage-dependent coupling between activation and fast inactivation [2].

Thus far, many toxins derived from sea anemones have been discovered and categorized under the 3 types: type I sea anemone toxins (Av2-like toxins); type II sea anemone toxins (Rp3-like toxins); and type III, which includes Av3 and Ea1 [115,117-119]. Toxins that belong to type I are powerful modulators of $\mathrm{NaV}$ channels that bind to site 3 at domain IV of the channel [120]. ATX II sequence was the first determined toxin [114] and was isolated from Anemonia sulcate, while Anthopleurin A was isolated from Anemonia xanthogrammica. Both toxins have inhibited the maximum gating charge of VGSCs. Mutagenesis studies showed that this reduction was due to the inhibition of S4 of domain IV in site 3, indicating the main binding site of these toxins [121]. Moreover, Anthopleurins are considered as type I NaV toxins and are isolated from the genus Anthopleura and can be potent on cardiac $\mathrm{NaV}[122,123]$. ATX III, which belongs to type III, has also been found to bind to site 3 . However, ATX III is not related to any other site 3 toxins [124]. Six ATX III toxins have been found until now from three different species (Anemonia viridis, Dofleinia armata and Entacmaea quadricolor). All of these toxins inhibit the inactivation of $\mathrm{Na}^{+}$current. Moreover, studies showed that various residues are present on the surface of these toxins and make a hydrophobic patch that could be part of the $\mathrm{NaV}$ channel binding surface [115]. ATX I and ATX III are highly active in insects and crustaceans but not in mice, whereas ATX II is active in both mice and crustaceans $[124,125]$.

Calitoxin I ( $\Delta$-hormotoxin-Cpt1a) and II ( $\Delta$-hormotoxin-Cpt1b), 79 amino acid residues long, belong to the type IV toxins. They are isolated from Calliactis parasitica and present a long chain and three disulfide bridges in common with types I and II $[109,126]$. Furthermore, they have a similar outcome on VGSCs as types I-III toxins [109]. In Table 2, the other, less documented toxins from sea anemones that are also active on the VGSCs are represented.

Table 2. Other toxins from sea anemones that target VGSCs.

\begin{tabular}{|c|c|c|c|}
\hline & Toxin & Source & References \\
\hline \multirow{11}{*}{ Type I } & ATX II and II & Anemonia viridis (Anemonia sulcata) & [112] \\
\hline & $\mathrm{ApA}$ and $\mathrm{ApB}$ & Anthopleura xanthogrammica & {$[127,128]$} \\
\hline & Ae I & Actinia equina & [129] \\
\hline & $\mathrm{Cp}$ I and II & Condylactis passiflora & [130] \\
\hline & Rc I & Radianthus (Heteractis) crispus & [131] \\
\hline & AFT I and II & Anthopleura fuscoviridis & [132] \\
\hline & Bc III & Bunodosoma caissarum & [133] \\
\hline & Bg II and III & Bunodosoma granulifera & [134] \\
\hline & Halcurin & Halcurias sp. & [135] \\
\hline & AETX I & Anemonia erythraea & [136] \\
\hline & Hk2 & Anthopleura sp. & [137] \\
\hline
\end{tabular}


Table 2. Cont.

\begin{tabular}{|c|c|c|c|}
\hline & Toxin & Source & References \\
\hline & ATX Ia and Ib & Anemonia sulcata & [138] \\
\hline & ATX II & Anemonia sulcata & [112] \\
\hline & ATX V & Anemonia sulcata & [139] \\
\hline & $\begin{array}{l}\text { PCR1-2, 2-1, 2-5, } \\
2-10,3-6, \text { and 3-7 }\end{array}$ & Anthopleura xanthogrammica & [140] \\
\hline & $\mathrm{ApC}$ & Anthopleura elegantissima & [141] \\
\hline & APE 1 to APE 5 & Anthopleura elegantissima & [142] \\
\hline & Cangitoxin & Bunodosoma cangicum & [143] \\
\hline & Am III & Antheopsis maculata & {$[144]$} \\
\hline & Gigantoxin II & Stichodactyla gigantea & [145] \\
\hline \multirow{4}{*}{ Type II } & RTX I, II, III, IV and V & Radianthus (Heteractis) macrodactylus & [146-148] \\
\hline & Gigantoxin III & Stichodactyla gigantea & [145] \\
\hline & Rp II, III & Radianthus (Heteractis) paumotensis & {$[117,149]$} \\
\hline & Sh I & Stichodactyla helianthus & [150] \\
\hline \multirow{6}{*}{ Type III } & \multirow{3}{*}{ ATXIII } & Anemonia viridis & \multirow{3}{*}[112,114,151]{} \\
\hline & & Dofleinia armata & \\
\hline & & Entacmaea quadricolor & \\
\hline & Da I and II & Dofleinia armata & [116] \\
\hline & Er I & Entacmaea ramsayi & [116] \\
\hline & Ea I(PaTx) & Entacmaea actinostoloides & [116] \\
\hline
\end{tabular}

\subsection{Toxins from Cone Snails}

The genus Conus, from the Conidae family, is a group of predatory gastropod mollusk that includes more than 500 different species. Cone snails belonging to this genus usually live in tropical waters [152]. They are categorized into three groups depending on their alimentation habits: mollusk hunters (molluscivorous), worm hunters (vermivorous), and fish hunters (piscivorous) [153]. They use their venom as a weapon to defend themselves and capture their prey [154]. The biotoxin of marine cone snails is a combination of many peptides that may vary between species. The venom of a single species can contain different toxins depending on its predatory or defensive use [155].

Conotoxins are small peptides rich in disulfide bridges found in the venom of conical snails [156]. First, cone snails produce propeptides in the secretory cells of their tubular venom duct. Then, the proteases cleave the precursor protein generating active conotoxins. The cone snail has a specialized harpoon-shaped root tooth used to inject its venom into its prey [157]. These conotoxins have shown a high affinity for various membrane receptors, ion channels, and transporters in the nervous system of target preys and predators that gave them a great value in the pharmaceutical field. According to their pharmacological activities and their molecular targets, conotoxins are grouped into different families [158]. Among the different families of conotoxins, four of them target VGSCs: $\mu-, \mu \mathrm{O}-, \delta-$, and $i$-conotoxins. Each of these families interacts with VGSCs by binding to specific sites on the channel $\alpha$ subunit. To date, only $\mu$ - and $\mu \mathrm{O}$-conotoxin families exhibit pain-relieving properties in animal models [159]. $\mu$ - and $\mu \mathrm{O}$-conotoxins inhibit the VGSC current-this happens when $\mu \mathrm{O}$-conotoxins bind to an external site to the pore that modifies the channel gating and closes the channel [160], while $\mu$-conotoxins bind to the external vestibule of the channel and thus sterically and electrostatically block the conductive pathway of ions [159]. Unlike $\mu$ - and $\mu \mathrm{O}$-conotoxins, $\delta$ - and $i$-conotoxins stimulate VGSC activity. The $\delta$-conotoxins interact with the hydrophobic surface residues of the S3/S4 linker of 
domain IV site 6. However, this interaction results in the prolongation of the opening of the channels that extends action potentials and activates a persistent neuronal discharge, eventually deferring or inhibiting rapid inactivation $[157,161]$. $i$-Conotoxins activate VGSC without affecting the inactivation by shifting the voltage dependence of activation to more hyperpolarized potentials or by improving the amplitude of the TTX-S $\mathrm{Na}^{+}$current in DRG neurons [162].

$\mu \mathrm{O}$-conotoxins belong to the $\mathrm{O}$-superfamily of conotoxins, and they are known to be moderately selective inhibitors of VGSC TTX-R currents in rat DRG neurons. These toxins are hydrophobic peptides made up of 28 to 32 amino acids. Each toxin contains three intramolecular disulfide bonds [163]. The site 4 receptor on the $\mathrm{NaV}$ channels is their target; they block the flow of $\mathrm{Na}^{+}$by preventing the voltage sensor in domain- 2 from activating and consequently the channel from opening [160]. To date, only two $\mu \mathrm{O}$-conotoxins have been identified: MrVIA and MrVIB from the venom of the mollusk-hunting species C. marmoreus [164]. MrVIA and MrVIB have high sequence homology, and they only differ by two residues. They are formed by 31-residue peptides with three disulfide bridges. The significance of MrVIA and MrVIB is in their ability to block TTX-R $\mathrm{Na}^{+}$currents in mammalian DRG neurons 10 times more than TTX-S Na+ currents $[163,165]$. As $\mu$ Oconotoxins act as gating modifiers, MrVIA inhibits $\mathrm{Na}^{+}$current in a voltage-dependent way with a reduction in affinity after depolarizing voltage steps [160]. The inhibition of TTX-R by MrVIB is more selective than that of TTX-S neuronal VGSCs and even selective between the different subtypes of VGSC TTX-R (100 times more selective for NaV1.8 than NaV1.9 in DRGs) [163]. Of the nine NaV subtypes, NaV1.8 is expressed in peripheral sensory neurons and is present in the majority of nociceptive neurons [166]. It contributes to the action potentials of the $\mathrm{Na}^{+}$current in the pain pathway. Therefore, it constitutes an interesting analgesic target.

After examination of the MrVIA binding site in the NaV1.4 channels and competition experiments with the scorpion toxin Ts1, it was identified that the C-terminal pore loop of DIII is required for the binding of MrVIA to NaV1.4. Alternatively, another study that used site-directed NaV1.4 mutagenesis showed that the DII domain is the main binding site of MrVIA while the DIII domain plays a less important role [160,167]. Studies have shown that the region between the S6 segment of DI and the outer loop of DII in NaV1.8 is responsible for the strong affinity of the $\mu \mathrm{O}$-conotoxin family for $\mathrm{NaV1.8}$ [168]. Comparable to MrVIA and MrVIB, a new MfVIA toxin from Conus magnificus has been identified [169]. MfVIA is a 32-residue hydrophobic peptide that has the highest sequence homology to MrVIB. However, what differs is the selectivity towards VGSC subtypes. MfVIA is three times more effective against NaV1.4 and five times less effective against NaV1.2 than MrVIA or MrVIB. It has the ability to inhibit NaV1.4 and NaV1.8 at low nanomolar concentrations, while significantly higher toxin concentrations are required to block all other VGSC subtypes [169]. $\mu \mathrm{O}$-Conotoxin includes a single toxin that binds and blocks the channel that is consistent with MfVIA and inhibits all VGSC subtypes except NaV1.2 [169]. Two new $\mu \mathrm{O}$-conotoxin LtVIC and LtVIIA were discovered after sequencing of $C$. litteratus. These two toxins inhibit VGSC channels in the same way that $\mu \mathrm{O}$-conotoxins do but their selectivity to VGSC subtypes must be further studied [170].

$\mu$-Conotoxins are relatively small sized peptides of 16 to 20 amino acids containing three disulfide bonds; they are rigid and highly basic. At least 12 different $\mu$-conotoxins have been identified thus far, with 6 of them being present in the venom of fish and molluschunting cone snails [171]. The first identified $\mu$-conotoxin was GIIIA from C. geographus. $\mu$-Conotoxins can bind to the pore region of VGSCs. The selectivity of these toxins for VGSC subtypes was primarily due to the differences in the turret region (S5-P loop link), as the near-pore differences are minimal [172]. GIIIA is a selective and potent blocker for skeletal muscle as it inhibits NaV1.4 with a nanomolar concentration [173]. While PIIIA was the first to inhibit neuronal VGSC, studies have shown its capacity to inhibit skeletal VGSC in mammalians [174]. KIIIA and SIIIA are two small sized $\mu$-conotoxins with high affinity, making them strong prospective therapeutic agents. Contrary to GIIIA, 
KIIIA binds to neuronal channel NaV1.2 and to NaV1.7 [175]. To understand how and to which VGSC domains do $\mu$-conotoxins bind to, researchers have studied chimeras of rat and human NaV1.4 and NaV1.5. SIIIA and CnIIIC are potent blockers of the VGSC subtypes $\mathrm{NaV1} 1.2$ and $\mathrm{NaV1.4}$, but inactive at $\mathrm{NaV1.8}$ and NaV1.5, alongside its inability to block NaV1.8 [176]. Furthermore, changes in the amino acid residue affect the affinity of $\mu$-conotoxins to bind to the $\mathrm{NaV}$ channels [177].

Conotoxins have been shown to be promising candidates in the therapeutic field due to their selectivity and affinity to VGSC and additional membrane receptors and ion channels. An analogue of the $\chi$-MrIA conotoxin is currently in phase II clinical trials for the treatment of neuropathic pain. Indeed, it inhibits the transporter of norepinephrine in a non-competitive way [178]. Preclinical trials have been completed for $\omega$-CVID, but this toxin exhibited cytotoxic effects in phase II. For the management of pain and intractable epilepsy, human clinical trials are underway for contulakin-G and conantokine-G $[179,180]$. As a result, many conopeptides are being developed for the control of pain and various diseases such as Parkinson's [181]. Furthermore, MrVIA, MrVIB, and MfVIA demonstrated high analgesic properties since they can inhibit NaV1.8, which has a fundamental role in the pathophysiology of pain. Nevertheless, the chemical composition of conopeptides as well as their folding properties make it difficult for researchers to synthetize a considerable number of them [182].

\section{Pharmaceutical Applications of Marine Toxins}

Assuming their pivotal role in the neuronal excitability and their high expression in pain-mediating sensory neurons, $\mathrm{NaV}$ channels are considered therapeutical targets in the context of acute and inflammatory pain [183]. Despite the availability of a wide variety of analgesic drugs, clinicians face a difficulty in managing pain that is resistant to standard treatments. Neurotoxins have been proven to possess an analgesic potential via blocking ion channels such as VGSC that play an important role in pain transmission. For this reason, scientists aimed to develop medicinal products using neurotoxins as pain killers. Additionally, several patents have been issued worldwide regarding the use of marine neurotoxins for the treatment of pain in humans. One method for inducing local analgesia in a mammal with pain in an epithelial tissue region consists of topically applying an appropriate amount of a long-acting NaV inhibitor, such as TTX or STX, to the affected area in a suitable pharmaceutical vehicle [184]. Systemic administration of TTX or STX in mammals experiencing pain induces analgesia [185]. Moreover, another strategy has been developed to target the neuropathic pain, a major public health issue. This technique came with the discovery that TTX has a high potency in treating central-nervous-derived neuropathic pain. It consists of using TTX, or STX, or their analogs with their tolerable physiological salts as a therapeutic product in patients suffering from central nervously derived neuropathic pain [186]. In addition, another method has combined TTX and opioid antagonists. It has been found that this combination has a surprising significant anti-pain effect, particularly in neuropathic pain, with an unanticipated overadditive impact [187].

For most patients with cancer, chemotherapy is one of the most used therapies to treat carcinomas. Chemotherapy is known to cause neuropathic pain, which in many cases leads to the failure of therapy. Moreover, allodynia and hyperalgesia can occur in a high percentage of patients. As a result, a drug has been developed for the treatment of neuropathic pain resulting from chemotherapy. The developed drug consists of VGSC blockers such as TTX or STX or their derivatives along with their adequate salts. The routes of administration of this drug can be a patch through skin, orally, subcutaneous injection, intramuscular injection, intravenous injection, etc. [188]. This same composition used in this drug was effective in treating preterm labor and/or premature birth, given that TTX effectively prevents uterine contractions [189]. Moreover, a method has been established for controlling musculoskeletal pain. The active compounds in this method are TTX or its derivatives and analogues as well as STX or its derivatives and analogues that can be given as tablets, patches, or by needles [190]. Interestingly, a TTX mask has been developed. This 
mask exerts many effects such as easing pain and relieving itching. The mask includes active medicinal ingredients such as TTX, citric acid as a complex solubilizer, lactose as a stabilizer, mint essential oil, zinc oxide, Vaseline, and rosin [191].

As previously mentioned, VGSCs are implicated in the pain signaling pathway. NaV1.7 loss-of-function mutations are responsible for a human congenital insensitivity to acute and chronic pain. Therefore, to inhibit NaV1.7,11,13-modified STX can be used as analgesic [192]. Another compound that has been developed to treat pain conditions in mammals is 10,11-modified STX [193]. The development of a special combination of NeoSTX, bupivacaine, and epinephrine has considerably prolonged the duration of full blockage to a mechanical stimulus [194]. On another note, TTX and STX are not only used in treating pain. A previous strategy was developed with the aim to be both safe and effective. This strategy is based on a formulation consisting of TTX, lidocaine hydrochloride, cosolvents, freeze-drying excipients, and stabilizing agents [195]. On the other hand, TTX, STX, and their analogues and derivatives are used to treat nicotine dependency. This technique is based on the capacity of TTX and STX to support the de-addiction mechanism [196].

Aside from TTX and STX, conotoxins have proven that they can be used as therapeutic agents. A recent strategy highlighted the possible use of conotoxins peptides in the medical field. Researchers have developed a $\mu$-conotoxin peptide essentially comprising the following amino acid sequence: Xaa1-Xaa2-Cys Cys-Xaa3-Xaa-4-Xaa5-Xaaé-Xaa1-Cys-Xaa8-Xaa9Xaa10-Xaa11-Cys-Xaa12-Xaa13-Xaa14-Xaa15-Xaa16-Cys-Cys-Xaa17, which constitutes a bioactive fragment that can be used in pharmaceutical composition for the treatment or prevention of diseases associated with VGSC [197].

\section{Conclusions}

The marine ecosystem is a complex of a wide variety of organisms that are a source of active toxins interacting with voltage-gated sodium channels (VGSCs). As previously described TTX, STX, and conotoxins play an important role as blockers of VGSC. Thus, they are endowed with analgesic properties and are the subject of research in the therapeutic field as drugs to manage pain. However, these neurotoxins must be administrated at very low doses and their toxicity must be well studied for the further development of safe and effective drugs.

Author Contributions: Conceptualization, J.M.S. and Z.F.; formal analysis, R.M., R.A.-N. and R.W.; investigation, C.M., C.L., J.M.S. and Z.F.; resources, Z.F.; writing-original draft preparation, R.M. and R.A.-N.; writing-review and editing, R.W., C.M., C.L., Z.F. and J.M.S.; supervision, Z.F.; project administration, Z.F. and J.M.S. All authors have read and agreed to the published version of the manuscript.

Funding: This research received no external funding.

Institutional Review Board Statement: Not applicable.

Informed Consent Statement: Not applicable.

Data Availability Statement: Not applicable.

Acknowledgments: The authors acknowledge the Lebanese University for its support.

Conflicts of Interest: The authors declare no conflict of interest.

\section{References}

1. Hodgkin, A.L.; Huxley, A.F. A quantitative description of membrane current and its application to conduction and excitation in nerve. J. Physiol. 1952, 117, 500-544. [CrossRef] [PubMed]

2. Stevens, M.; Peigneur, S.; Tytgat, J. Neurotoxins and Their Binding Areas on Voltage-Gated Sodium Channels. Front. Pharmacol. 2011, 2, 71. [CrossRef] [PubMed]

3. Shilpi, J.A.; Uddin, S.J. Chapter Fourteen-Analgesic and antipyretic natural products. Annu. Rep. Med. Chem. 2020, 55, 435-458.

4. Kim, J.-B. Channelopathies. Korean J. Pediatr. 2014, 57, 1-18. [CrossRef] [PubMed]

5. Dworakowska, B.; Dołowy, K. Ion channels-related diseases. Acta Biochim. Pol. 2000, 47, 685-703. [CrossRef]

6. Benarroch, E.E. Sodium channels and pain. Neurology 2007, 68, 233-236. [CrossRef] 
7. de Lera Ruiz, M.; Kraus, R.L. Voltage-Gated Sodium Channels: Structure, Function, Pharmacology, and Clinical Indications. J. Med. Chem. 2015, 58, 7093-7118. [CrossRef]

8. Durán-Riveroll, L.M.; Cembella, A.D. Guanidinium Toxins and Their Interactions with Voltage-Gated Sodium Ion Channels. Mar. Drugs 2017, 15, 303. [CrossRef]

9. Stock, L.; Souza, C.; Treptow, W. Structural Basis for Activation of Voltage-Gated Cation Channels. Biochemistry 2013, 52, 1501-1513. [CrossRef]

10. Black, J.A.; Waxman, S.G. Noncanonical Roles of Voltage-Gated Sodium Channels. Neuron 2013, 80, 280-291. [CrossRef]

11. Catterall, W.A. From ionic currents to molecular mechanisms: The structure and function of voltage-gated sodium channels. Neuron 2000, 26, 13-25. [CrossRef]

12. Catterall, W.A.; Goldin, A.L.; Waxman, S.G. International Union of Pharmacology. XLVII. Nomenclature and Structure-Function Relationships of Voltage-Gated Sodium Channels. Pharmacol. Rev. 2005, 57, 397-409. [CrossRef] [PubMed]

13. Mattei, C.; Legros, C. The voltage-gated sodium channel: A major target of marine neurotoxins. Toxicon 2014, 91, 84-95. [CrossRef] [PubMed]

14. Ragsdale, D.S.; McPhee, J.C.; Scheuer, T.; Catterall, W.A. Common molecular determinants of local anesthetic, antiarrhythmic, and anticonvulsant block of voltage-gated Na+ channels. Proc. Natl. Acad. Sci. USA 1996, 93, 9270-9275. [CrossRef] [PubMed]

15. Kotipoyina, H.R.; Kong, E.L.; Warrington, S.J. Tetrodotoxin Toxicity; StatPearls Publishing: Treasure Island, FL, USA, 2021. Available online: http:/ / www.ncbi.nlm.nih.gov/books/NBK507714/ (accessed on 11 August 2021).

16. Narahashi, T. Tetrodotoxin. In Encyclopedia of the Neurological Sciences; Academic Press: Cambridge, MA, USA, $2014 ;$ pp. 420-422.

17. Fozzard, H.A.; Lipkind, G.M. The Tetrodotoxin Binding Site Is within the Outer Vestibule of the Sodium Channel. Mar. Drugs 2010, 8, 219-234. [CrossRef] [PubMed]

18. Chen, R.; Chung, S.-H. Mechanism of tetrodotoxin block and resistance in sodium channels. Biochem. Biophys. Res. Commun. 2014, 446, 370-374. [CrossRef]

19. Lee, C.H.; Ruben, P.C. Interaction between voltage-gated sodium channels and the neurotoxin, tetrodotoxin. Channels 2008, 2, 407-412. [CrossRef]

20. Narahashi, T.; Moore, J.W.; Scott, W.R. Tetrodotoxin blockage of sodium conductance increase in Lobster giant axons. J. Gen. Physiol. 1964, 47, 965-974. [CrossRef]

21. Narahashi, T. Tetrodotoxin: A brief history. Proc. Jpn. Acad Ser. B Phys. Biol. Sci. 2008, 84, 147-154. [CrossRef]

22. Pratheepa, V.; Vasconcelos, V. Binding and Pharmacokinetics of the Sodium Channel Blocking Toxins (Saxitoxin and the Tetrodotoxins). Mini Rev. Med Chem. 2017, 17, 320-327. [CrossRef]

23. Mattei, C. Tetrodotoxin, a Candidate Drug for Nav1.1-Induced Mechanical Pain? Mar. Drugs 2018, 16, 72. [CrossRef] [PubMed]

24. Beloeil, H.; Ababneh, Z.; Chung, R.; Zurakowski, D.; Mulkern, R.V.; Berde, C.B. Effects of bupivacaine and tetrodotoxin on carrageenan-induced hind paw inflammation in rats (Part 1): Hyperalgesia, edema, and systemic cytokines. Anesthesiology 2006, 105, 128-138. [CrossRef] [PubMed]

25. Iwamoto, T.; Takasugi, Y.; Higashino, H.; Ito, H.; Koga, Y.; Nakao, S. Antinociceptive action of carbamazepine on thermal hypersensitive pain at spinal level in a rat model of adjuvant-induced chronic inflammation. J. Anesth. 2011, 25, 78-86. [CrossRef] [PubMed]

26. Schwartz, D.M.; Duncan, K.G.; Fields, H.L.; Jones, M.R. Tetrodotoxin: Anesthetic activity in the de-epithelialized cornea. Graefes Arch. Clin. Exp. Ophthalmol. 1998, 236, 790-794. [CrossRef]

27. Schwartz, D.M.; Fields, H.L.; Duncan, K.G.; Duncan, J.L.; Jones, M.R. Experimental study of tetrodotoxin, a long-acting topical anesthetic. Am. J. Ophthalmol. 1998, 125, 481-487. [CrossRef]

28. Omana-Zapata, I.; Khabbaz, M.A.; Hunter, J.C.; Clarke, D.E.; Bley, K.R. Tetrodotoxin inhibits neuropathic ectopic activity in neuromas, dorsal root ganglia and dorsal horn neurons. Pain 1997, 72, 41-49. [CrossRef]

29. Marcil, J.; Walczak, J.-S.; Guindon, J.; Ngoc, A.H.; Lu, S.; Beaulieu, P. Antinociceptive effects of tetrodotoxin (TTX) in rodents. Br. J. Anaesth. 2006, 96, 761-768. [CrossRef]

30. González-Cano, R.; Tejada, M.Á.; Artacho-Cordón, A.; Nieto, F.R.; Entrena, J.M.; Wood, J.N.; Cendán, C.M. Effects of Tetrodotoxin in Mouse Models of Visceral Pain. Mar. Drugs 2017, 15, 188. [CrossRef] [PubMed]

31. Shen, H.; Liu, D.; Wu, K.; Lei, J.; Yan, N. Structures of human Nav1.7 channel in complex with auxiliary subunits and animal toxins. Science 2019, 363, 1303-1308. [CrossRef]

32. Hagen, N.A.; Fisher, K.M.; Lapointe, B.; du Souich, P.; Chary, S.; Moulin, D.; Sellers, E.; Ngoc, A.H. An open-label, multi-dose efficacy and safety study of intramuscular tetrodotoxin in patients with severe cancer-related pain. J. Pain Symptom. Manag. 2007, 34, 171-182. [CrossRef]

33. Hagen, N.A.; Lapointe, B.; Ong-Lam, M.; Dubuc, B.; Walde, D.; Gagnon, B.; Love, R.; Goel, R.; Hawley, P.; Ngoc, A.H.; et al. A multicentre open-label safety and efficacy study of tetrodotoxin for cancer pain. Curr. Oncol. 2011, 18, 109-116. [CrossRef]

34. Hagen, N.A.; Cantin, L.; Constant, J.; Haller, T.; Blaise, G.; Ong-Lam, M.; du Souich, P.; Korz, W.; Lapointe, B. Tetrodotoxin for Moderate to Severe Cancer-Related Pain: A Multicentre, Randomized, Double-Blind, Placebo-Controlled, Parallel-Design Trial. Pain Res. Manag. 2017, 2017, 7212713. [CrossRef]

35. Goldlust, S.A.; Kavoosi, M.; Nezzer, J.; Kavoosi, M.; Korz, W.; Deck, K. Tetrodotoxin for Chemotherapy-Induced Neuropathic Pain: A Randomized, Double-Blind, Placebo-Controlled, Parallel-Dose Finding Trial. Toxins 2021, 13, 235. [CrossRef] 
36. Hong, B.; Sun, J.; Zheng, H.; Le, Q.; Wang, C.; Bai, K.; He, J.; He, H.; Dong, Y.l. Effect of Tetrodotoxin Pellets in a Rat Model of Postherpetic Neuralgia. Mar. Drugs 2018, 16, 195. [CrossRef]

37. Nieto, F.R.; Entrena, J.M.; Cendán, C.M.; Del Pozo, E.; Vela, J.M.; Baeyens, J.M. Tetrodotoxin inhibits the development and expression of neuropathic pain induced by paclitaxel in mice. Pain 2008, 137, 520-531. [CrossRef]

38. Benyamin, R.; Trescot, A.M.; Datta, S.; Buenaventura, R.; Adlaka, R.; Sehgal, N.; Glaser, S.E.; Vallejo, R. Opioid complications and side effects. Pain Physician. 2008, 11, 105-120. [CrossRef]

39. Salas, M.M.; McIntyre, M.K.; Petz, L.N.; Korz, W.; Wong, D.; Clifford, J.L. Tetrodotoxin suppresses thermal hyperalgesia and mechanical allodynia in a rat full thickness thermal injury pain model. Neurosci. Lett. 2015, 607, 108-113. [CrossRef] [PubMed]

40. Xie, W.; Strong, J.A.; Meij, J.T.A.; Zhang, J.-M.; Yu, L. Neuropathic pain: Early spontaneous afferent activity is the trigger. Pain 2005, 116, 243-256. [CrossRef] [PubMed]

41. Zhang, L.; Xie, R.; Yang, J.; Zhao, Y.; Qi, C.; Bian, G.; Wang, M.; Shan, J.; Wang, C.; Wang, D.; et al. Chronic pain induces nociceptive neurogenesis in dorsal root ganglia from Sox2-positive satellite cells. Glia 2019, 67, 1062-1075. [CrossRef] [PubMed]

42. Shi, J.; Liu, T.-T.; Wang, X.; Epstein, D.H.; Zhao, L.-Y.; Zhang, X.-L.; Lu, L. Tetrodotoxin reduces cue-induced drug craving and anxiety in abstinent heroin addicts. Pharmacol. Biochem. Behav. 2009, 92, 603-607. [CrossRef]

43. Kavoosi, M.; O’Reilly, T.E.; Kavoosi, M.; Chai, P.; Engel, C.; Korz, W.; Gallen, C.C.; Lester, R.M. Safety, Tolerability, Pharmacokinetics, and Concentration-QTc Analysis of Tetrodotoxin: A Randomized, Dose Escalation Study in Healthy Adults. Toxins 2020, 12, 511. [CrossRef] [PubMed]

44. Liu, Q.; Santamaria, C.M.; Wei, T.; Zhao, C.; Ji, T.; Yang, T.; Shomorony, A.; Wang, B.Y.; Kohane, D.S. Hollow Silica Nanoparticles Penetrate the Peripheral Nerve and Enhance the Nerve Blockade from Tetrodotoxin. Nano Lett. 2018, 18, 32-37. [CrossRef]

45. Lopes, L.B.; Garcia, M.T.J.; Bentley, M.V.L.B. Chemical penetration enhancers. Ther. Deliv. 2015, 6, 1053-1061. [CrossRef] [PubMed]

46. Melnikova, D.I.; Khotimchenko, Y.S.; Magarlamov, T.Y. Addressing the Issue of Tetrodotoxin Targeting. Mar. Drugs 2018, 16, 352. [CrossRef] [PubMed]

47. Kohane, D.S.; Yieh, J.; Lu, N.T.; Langer, R.; Strichartz, G.R.; Berde, C.B. A re-examination of tetrodotoxin for prolonged duration local anesthesia. Anesthesiology 1998, 89, 119-131. [CrossRef]

48. Berde, C.B.; Athiraman, U.; Yahalom, B.; Zurakowski, D.; Corfas, G.; Bognet, C. Tetrodotoxin-bupivacaine-epinephrine combinations for prolonged local anesthesia. Mar. Drugs 2011, 9, 2717-2728. [CrossRef]

49. Santamaria, C.M.; Zhan, C.; McAlvin, B.; Zurakowski, D.; Kohane, D.S. Tetrodotoxin, epinephrine, and chemical permeation enhancer combinations in peripheral nerve blockade. Anesth. Analg. 2017, 124, 1804-1812. [CrossRef]

50. Shomorony, A.; Santamaria, C.M.; Zhao, C.; Rwei, A.Y.; Mehta, M.; Zurakowski, D.; Kohane, D.S. Prolonged Duration Local Anesthesia by Combined Delivery of Capsaicin- and Tetrodotoxin-Loaded Liposomes. Anesth. Analg. 2019, 129, $709-717$. [CrossRef]

51. Larsson, M.E.; Laczka, O.F.; Harwood, D.T.; Lewis, R.J.; Himaya, S.W.A.; Murray, S.A.; Doblin, M.A. Toxicology of Gambierdiscus spp. (Dinophyceae) from Tropical and Temperate Australian Waters. Mar. Drugs 2018, 16, 7. [CrossRef]

52. Mattei, C.; Vetter, I.; Eisenblätter, A.; Krock, B.; Ebbecke, M.; Desel, H.; Zimmermann, K. Ciguatera fish poisoning: A first epidemic in Germany highlights an increasing risk for European countries. Toxicon 2014, 91, 76-83. [CrossRef]

53. Friedman, M.A.; Fernandez, M.; Backer, L.C.; Dickey, R.W.; Bernstein, J.; Schrank, K.; Kibler, S.; Stephan, W.; Gribble, M.O.; Bienfang, P.; et al. An Updated Review of Ciguatera Fish Poisoning: Clinical, Epidemiological, Environmental, and Public Health Management. Mar. Drugs 2017, 15, 72. [CrossRef] [PubMed]

54. Bidard, J.N.; Vijverberg, H.P.; Frelin, C.; Chungue, E.; Legrand, A.M.; Bagnis, R.; Lazdunski, M. Ciguatoxin is a novel type of Na ${ }^{+}$ channel toxin. J. Biol. Chem. 1984, 259, 8353-8357. [CrossRef]

55. Lombet, A.; Bidard, J.N.; Lazdunski, M. Ciguatoxin and brevetoxins share a common receptor site on the neuronal voltagedependent Na+ channel. FEBS Lett. 1987, 219, 355-359. [CrossRef]

56. Benoit, E.; Juzans, P.; Legrand, A.-M.; Molgo, J. Nodal swelling produced by ciguatoxin-induced selective activation of sodium channels in myelinated nerve fibers. Neuroscience 1996, 71, 1121-1131. [CrossRef]

57. Strachan, L.C.; Lewis, R.J.; Nicholson, G.M. Differential actions of pacific ciguatoxin-1 on sodium channel subtypes in mammalian sensory neurons. J. Pharmacol. Exp. Ther. 1999, 288, 379-388. [PubMed]

58. Mattei, C.; Molgó, J.; Benoit, E. Involvement of both sodium influx and potassium efflux in ciguatoxin-induced nodal swelling of frog myelinated axons. Neuropharmacology 2014, 85, 417-426. [CrossRef] [PubMed]

59. Zhang, F.; Xu, X.; Li, T.; Liu, Z. Shellfish Toxins Targeting Voltage-Gated Sodium Channels. Mar. Drugs 2013, 11, 4698-4723. [CrossRef]

60. Gilchrist, J.; Olivera, B.M.; Bosmans, F. Animal Toxins Influence Voltage-Gated Sodium Channel Function. Handb Exp. Pharmacol. 2014, 221, 203-229.

61. Llewellyn, L.E. Saxitoxin, a toxic marine natural product that targets a multitude of receptors. Nat. Prod. Rep. 2006, 23, 200-222. [CrossRef]

62. Botana, L.M. Seafood and Freshwater Toxins: Pharmacology, Physiology, and Detection, 3rd ed.; CRC Press: Boca Raton, FL, USA, 2014; p. 1218.

63. Henderson, R.; Ritchie, J.M.; Strichartz, G.R. Evidence that tetrodotoxin and saxitoxin act at a metal cation binding site in the sodium channels of nerve membrane. Proc. Natl. Acad. Sci. USA 1974, 71, 3936-3940. [CrossRef] [PubMed] 
64. Adams, H.J.; Blair, M.R.; Takman, B.H. The local anesthetic activity of saxitoxin alone and with vasoconstrictor and local anesthetic agents. Arch. Int. Pharmacodyn Ther. 1976, 224, 275-282. [PubMed]

65. Duncan, K.G.; Duncan, J.L.; Schwartz, D.M. Saxitoxin: An anesthetic of the deepithelialized rabbit cornea. Cornea 2001, 20, 639-642. [CrossRef]

66. Barnet, C.S.; Tse, J.Y.; Kohane, D.S. Site 1 sodium channel blockers prolong the duration of sciatic nerve blockade from tricyclic antidepressants. Pain 2004, 110, 432-438. [CrossRef]

67. McAlvin, J.B.; Zhan, C.; Dohlman, J.C.; Kolovou, P.E.; Salvador-Culla, B.; Kohane, D.S. Corneal Anesthesia with Site 1 Sodium Channel Blockers and Dexmedetomidine. Investig. Ophthalmol Vis. Sci. 2015, 56, 3820-3826. [CrossRef] [PubMed]

68. Epstein-Barash, H.; Shichor, I.; Kwon, A.H.; Hall, S.; Lawlor, M.W.; Langer, R.; Kohane, D.S. Prolonged Duration Local Anesthesia with Minimal Toxicity. Proc. Natl. Acad. Sci. USA 2009, 106, 7125-7130. [CrossRef]

69. Wiese, M.; D’Agostino, P.M.; Mihali, T.K.; Moffitt, M.C.; Neilan, B.A. Neurotoxic Alkaloids: Saxitoxin and Its Analogs. Mar. Drugs 2010, 8, 2185-2211. [CrossRef]

70. Adachi, K.; Ishizuka, H.; Odagi, M.; Nagasawa, K. Synthetic Approaches to Zetekitoxin AB, a Potent Voltage-Gated Sodium Channel Inhibitor. Mar. Drugs 2019, 18, 24. [CrossRef]

71. Beckley, J.T.; Pajouhesh, H.; Luu, G.; Klas, S.; Delwig, A.; Monteleone, D.; Zhou, X.; Giuvelis, D.; Meng, I.D.; Yeomans, D.C.; et al. Antinociceptive properties of an isoform-selective inhibitor of Nav1.7 derived from saxitoxin in mouse models of pain. Pain 2021, 162, 1250-1261. [CrossRef] [PubMed]

72. Rodriguez-Navarro, A.J.; Lagos, N.; Lagos, M.; Braghetto, I.; Csendes, A.; Hamilton, J.; Figueroa, C.; Truan, D.; Garcia, C.; Rojas, A.; et al. Neosaxitoxin as a local anesthetic: Preliminary observations from a first human trial. Anesthesiology 2007, 106, 339-345. [CrossRef] [PubMed]

73. Lobo, K.; Donado, C.; Cornelissen, L.; Kim, J.; Ortiz, R.; Peake, R.W.A.; Kellogg, M.; Alexander, M.E.; Zurakowski, D.; Kurgansky, K.E.; et al. A Phase 1, Dose-escalation, Double-blind, Block-randomized, Controlled Trial of Safety and Efficacy of Neosaxitoxin Alone and in Combination with 0.2\% Bupivacaine, with and without Epinephrine, for Cutaneous Anesthesia. Anesthesiology 2015, 123, 873-885. [CrossRef]

74. Rodriguez-Navarro, A.J.; Lagos, M.; Figueroa, C.; Garcia, C.; Recabal, P.; Silva, P.; Iglesias, V.; Lagos, N. Potentiation of local anesthetic activity of neosaxitoxin with bupivacaine or epinephrine: Development of a long-acting pain blocker. Neurotox Res. 2009, 16, 408-415. [CrossRef]

75. Valenzuela, C.; Torres, C.; Muñoz, V.; Simbaina, J.C.; Sánchez, A.; Bustamante, T.; Sepúlveda, J.M.; Piron, R.; Del Campo, M.; Lagos, N. Evaluation of Neosaxitoxin as a local anesthetic during piglet castration: A potential alternative for Lidocaine. Toxicon 2019, 164, 26-30. [CrossRef] [PubMed]

76. Manríquez, V.; Castro Caperan, D.; Guzmán, R.; Naser, M.; Iglesia, V.; Lagos, N. First evidence of neosaxitoxin as a long-acting pain blocker in bladder pain syndrome. Int. Urogynecol. J. 2015, 26, 853-858. [CrossRef]

77. Rodríguez-Navarro, A.J.; Berde, C.B.; Wiedmaier, G.; Mercado, A.; Garcia, C.; Iglesias, V.; Zurakowski, D. Comparison of neosaxitoxin versus bupivacaine via port infiltration for postoperative analgesia following laparoscopic cholecystectomy: A randomized, double-blind trial. Reg. Anesth. Pain Med. 2011, 36, 103-109. [CrossRef]

78. Galindo, J.; Contreras, M.; Maldonado, P.; Torrealba, F.; Lagos, N.; Valdés, J.L. Long-lasting, reversible and non-neurotoxic inactivation of hippocampus activity induced by neosaxitoxin. J. Neurosci. Methods. 2018, 308, 197-204. [CrossRef]

79. Lattes, K.; Venegas, P.; Lagos, N.; Lagos, M.; Pedraza, L.; Rodriguez-Navarro, A.J.; García, C. Local infiltration of gonyautoxin is safe and effective in treatment of chronic tension-type headache. Neurol. Res. 2009, 31, 228-233. [CrossRef]

80. Hinzpeter, J.; Barrientos, C.; Zamorano, Á.; Martinez, Á.; Palet, M.; Wulf, R.; Barahona, M.; Sepúlveda, J.M.; Guerra, M.; Bustamante, T.; et al. Gonyautoxins: First evidence in pain management in total knee arthroplasty. Toxicon 2016, 119, 180-185. [CrossRef] [PubMed]

81. Wang, D.-Z. Neurotoxins from marine dinoflagellates: A brief review. Mar. Drugs 2008, 6, 349-371. [CrossRef]

82. Watkins, S.M.; Reich, A.; Fleming, L.E.; Hammond, R. Neurotoxic shellfish poisoning. Mar. Drugs 2008, 6, 431-455. [CrossRef] [PubMed]

83. Baden, D.G.; Tomas, C.R. Variations in major toxin composition for six clones of Ptychodiscus brevis. Toxicon 1988, 26, 961-963. [CrossRef]

84. Poli, M.A.; Musser, S.M.; Dickey, R.W.; Eilers, P.P.; Hall, S. Neurotoxic shellfish poisoning and brevetoxin metabolites: A case study from Florida. Toxicon 2000, 38, 981-993. [CrossRef]

85. Morris, P.D.; Campbell, D.S.; Taylor, T.J.; Freeman, J.I. Clinical and epidemiological features of neurotoxic shellfish poisoning in North Carolina. Am. J. Public Health 1991, 81, 471-474. [CrossRef] [PubMed]

86. Wang, S.-Y.; Wang, G.K. Voltage-gated sodium channels as primary targets of diverse lipid-soluble neurotoxins. Cell Signal. 2003, 15, 151-159. [CrossRef]

87. Baden, D.G.; Bourdelais, A.J.; Jacocks, H.; Michelliza, S.; Naar, J. Natural and Derivative Brevetoxins: Historical Background, Multiplicity, and Effects. Environ. Health Perspect. 2005, 113, 621-625. [CrossRef] [PubMed]

88. Rein, K.S.; Baden, D.G.; Gawley, R.E. Conformational Analysis of the Sodium Channel Modulator, Brevetoxin A, Comparison with Brevetoxin B Conformations, and a Hypothesis about the Common Pharmacophore of the "Site 5" Toxins. J. Org. Chem. 1994, 59, 2101-2106. [CrossRef] 
89. Trainer, V.L.; Baden, D.G.; Catterall, W.A. Identification of peptide components of the brevetoxin receptor site of rat brain sodium channels. J. Biol. Chem. 1994, 269, 19904-19909. [CrossRef]

90. Sequeira, E.; Pierce, M.L.; Akasheh, D.; Sellers, S.; Gerwick, W.H.; Baden, D.G.; Murray, T.F. Epicortical Brevetoxin Treatment Promotes Neural Repair and Functional Recovery after Ischemic Stroke. Mar. Drugs 2020, 18, 374. [CrossRef] [PubMed]

91. Orjala, J.; Nagle, D.G.; Hsu, V.; Gerwick, W.H. Antillatoxin: An Exceptionally Ichthyotoxic Cyclic Lipopeptide from the Tropical Cyanobacterium Lyngbya majuscula. J. Am. Chem. Soc. 1995, 117, 8281-8282. [CrossRef]

92. Berman, F.W.; Gerwick, W.H.; Murray, T.F. Antillatoxin and kalkitoxin, ichthyotoxins from the tropical cyanobacterium Lyngbya majuscula, induce distinct temporal patterns of NMDA receptor-mediated neurotoxicity. Toxicon 1999, 37, 1645-1648. [CrossRef]

93. Osborne, N.J.; Webb, P.M.; Shaw, G.R. The toxins of Lyngbya majuscula and their human and ecological health effects. Environ. Int. 2001, 27, 381-392. [CrossRef]

94. Cao, Z.; George, J.; Gerwick, W.H.; Baden, D.G.; Rainier, J.D.; Murray, T.F. Influence of lipid-soluble gating modifier toxins on sodium influx in neocortical neurons. J. Pharmacol. Exp. Ther. 2008, 326, 604-613. [CrossRef]

95. Li, W.I.; Berman, F.W.; Okino, T.; Yokokawa, F.; Shioiri, T.; Gerwick, W.H.; Murray, T.F. Antillatoxin is a marine cyanobacterial toxin that potently activates voltage-gated sodium channels. Proc. Natl. Acad. Sci. USA 2001, 98, 7599-7604. [CrossRef] [PubMed]

96. Cao, Z.; Gerwick, W.H.; Murray, T.F. Antillatoxin is a sodium channel activator that displays unique efficacy in heterologously expressed rNav1.2, rNav1.4 and rNav1.5 alpha subunits. BMC Neurosci. 2010, 11, 154. [CrossRef] [PubMed]

97. Wu, M.; Okino, T.; Nogle, L.M.; Marquez, B.L.; Williamson, R.T.; Sitachitta, N. Structure, Synthesis, and Biological Properties of Kalkitoxin, a Novel Neurotoxin from the Marine Cyanobacterium Lyngbya majuscula. J. Am. Chem Soc. 2000, 122, 12041-12042. [CrossRef]

98. LePage, K.T.; Goeger, D.; Yokokawa, F.; Asano, T.; Shioiri, T.; Gerwick, W.H.; Murray, T.F. The neurotoxic lipopeptide kalkitoxin interacts with voltage-sensitive sodium channels in cerebellar granule neurons. Toxicol. Lett. 2005, 158, 133-139. [CrossRef]

99. Edwards, D.J.; Marquez, B.L.; Nogle, L.M.; McPhail, K.; Goeger, D.E.; Roberts, M.A.; Gerwick, W.H. Structure and biosynthesis of the jamaicamides, new mixed polyketide-peptide neurotoxins from the marine cyanobacterium Lyngbya majuscula. Chem. Biol. 2004, 11, 817-833. [CrossRef]

100. Choi, H.; Engene, N.; Smith, J.E.; Preskitt, L.B.; Gerwick, W.H. Crossbyanols A-D, toxic brominated polyphenyl ethers from the Hawai'ian bloom-forming Cyanobacterium Leptolyngbya crossbyana. J. Nat. Prod. 2010, 73, 517-522. [CrossRef] [PubMed]

101. Pereira, A.; Cao, Z.; Murray, T.F.; Gerwick, W.H. Hoiamide a, a sodium channel activator of unusual architecture from a consortium of two papua new Guinea cyanobacteria. Chem. Biol. 2009, 16, 893-906. [CrossRef]

102. Choi, H.; Pereira, A.R.; Cao, Z.; Shuman, C.F.; Engene, N.; Byrum, T.; Matainaho, T.; Murray, T.F.; Mangoni, A.; Gerwick, W.H. The Hoiamides, Structurally Intriguing Neurotoxic Lipopeptides from Papua New Guinea Marine Cyanobacteria. J. Nat. Prod. 2010, 73, 1411-1421. [CrossRef] [PubMed]

103. Pereira, A.R.; Cao, Z.; Engene, N.; Soria-Mercado, I.E.; Murray, T.F.; Gerwick, W.H. Palmyrolide A, an Unusually Stabilized Neuroactive Macrolide from Palmyra Atoll Cyanobacteria. Org. Lett. 2010, 12, 4490-4493. [CrossRef]

104. Taniguchi, M.; Nunnery, J.K.; Engene, N.; Esquenazi, E.; Byrum, T.; Dorrestein, P.C.; Gerwick, W.H. Palmyramide A, a cyclic depsipeptide from a Palmyra Atoll collection of the marine cyanobacterium Lyngbya majuscula. J. Nat. Prod. 2010, 73, 393-398. [CrossRef] [PubMed]

105. Reft, A.J.; Daly, M. Morphology, distribution, and evolution of apical structure of nematocysts in hexacorallia. J. Morphol. 2012, 273, 121-136. [CrossRef] [PubMed]

106. Moran, Y.; Genikhovich, G.; Gordon, D.; Wienkoop, S.; Zenkert, C.; Özbek, S.; Technau, U.; Gurevitz, M. Neurotoxin localization to ectodermal gland cells uncovers an alternative mechanism of venom delivery in sea anemones. Proc. Biol. Sci. 2012, 279, 1351-1358. [CrossRef] [PubMed]

107. David, C.N.; Ozbek, S.; Adamczyk, P.; Meier, S.; Pauly, B.; Chapman, J.; Hwang, J.S.; Gojobori, T.; Holstein, T.W. Evolution of complex structures: Minicollagens shape the cnidarian nematocyst. Trends Genet. 2008, 24, 431-438. [CrossRef] [PubMed]

108. Norton, R.S. Structure and structure-function relationships of sea anemone proteins that interact with the sodium channel. Toxicon 1991, 29, 1051-1084. [CrossRef]

109. Honma, T.; Shiomi, K. Peptide Toxins in Sea Anemones: Structural and Functional Aspects. Mar. Biotechnol. 2006, 8, 1-10. [CrossRef] [PubMed]

110. Martins, R.D.; Alves, R.S.; Martins, A.M.C.; Barbosa, P.S.F.; Evangelista, J.S.A.M.; Evangelista, J.J.F.; Ximenes, R.M.; Toyama, M.H.; Toyama, D.O.; Souza, A.J.; et al. Purification and characterization of the biological effects of phospholipase A(2) from sea anemone Bunodosoma caissarum. Toxicon 2009, 54, 413-420. [CrossRef] [PubMed]

111. Suput, D. In vivo effects of cnidarian toxins and venoms. Toxicon 2009, 54, 1190-1200. [CrossRef]

112. Wunderer, G.; Fritz, H.; Wachter, E.; Machleidt, W. Amino-acid sequence of a coelenterate toxin: Toxin II from Anemonia sulcata. Eur. J. Biochem. 1976, 68, 193-198. [CrossRef]

113. Wunderer, G.; Eulitz, M. Amino-acid sequence of toxin I from Anemonia sulcata. Eur. J. Biochem. 1978, 89, 11-17. [CrossRef]

114. Martinez, G.; Kopeyan, C. Toxin III from Anemonia sulcata: Primary structure. FEBS Lett. 1977, 84, 247-252. [CrossRef]

115. Manoleras, N.; Norton, R.S. Three-dimensional structure in solution of neurotoxin III from the sea anemone Anemonia sulcata. Biochemistry 1994, 33, 11051-11061. [CrossRef]

116. Honma, T.; Iso, T.; Ishida, M.; Nagashima, Y.; Shiomi, K. Occurrence of type 3 sodium channel peptide toxins in two species of sea anemones (Dofleinia armata and Entacmaea ramsayi). Toxicon 2003, 41, 637-639. [CrossRef] 
117. Schweitz, H.; Bidard, J.N.; Frelin, C.; Pauron, D.; Vijverberg, H.P.; Mahasneh, D.M.; Lazdunski, M.; Vilbois, F.; Tsugita, A. Purification, sequence, and pharmacological properties of sea anemone toxins from Radianthus paumotensis. A new class of sea anemone toxins acting on the sodium channel. Biochemistry 1985, 24, 3554-3561. [CrossRef]

118. Salceda, E.; Pérez-Castells, J.; López-Méndez, B.; Garateix, A.; Salazar, H.; López, O.; Aneiros, A.; Ständker, L.; Béress, L.; Forssmann, W.G.; et al. CgNa, a type I toxin from the giant Caribbean sea anemone Condylactis gigantea shows structural similarities to both type I and II toxins, as well as distinctive structural and functional properties(1). Biochem. J. 2007, 406, 67-76. [CrossRef] [PubMed]

119. Moran, Y.; Gordon, D.; Gurevitz, M. Sea anemone toxins affecting voltage-gated sodium channels-molecular and evolutionary features. Toxicon 2009, 54, 1089-1101. [CrossRef]

120. Catterall, W.A.; Beress, L. Sea anemone toxin and scorpion toxin share a common receptor site associated with the action potential sodium ionophore. J. Biol. Chem. 1978, 253, 7393-7396. [CrossRef]

121. Sheets, M.F.; Kyle, J.W.; Kallen, R.G.; Hanck, D.A. The Na Channel Voltage Sensor Associated with Inactivation Is Localized to the External Charged Residues of Domain IV, S4. Biophys. J. 1999, 77, 747-757. [CrossRef]

122. Norton, T.R.; Shibata, S.; Kashiwagi, M.; Bentley, J. Isolation and characterization of the cardiotonic polypeptide anthopleurin-A from the sea anemone Anthopleura xanthogrammica. J. Pharm. Sci. 1976, 65, 1368-1374. [CrossRef]

123. Khera, P.K.; Benzinger, G.R.; Lipkind, G.; Drum, C.L.; Hanck, D.A.; Blumenthal, K.M. Multiple cationic residues of anthopleurin $\mathrm{B}$ that determine high affinity and channel isoform discrimination. Biochemistry 1995, 34, 8533-8541. [CrossRef]

124. Moran, Y.; Kahn, R.; Cohen, L.; Gur, M.; Karbat, I.; Gordon, D.; Gurevitz, M. Molecular analysis of the sea anemone toxin Av3 reveals selectivity to insects and demonstrates the heterogeneity of receptor site-3 on voltage-gated Na+ channels. Biochem. J. 2007, 406, 41-48. [CrossRef] [PubMed]

125. Schweitz, H.; Vincent, J.P.; Barhanin, J.; Frelin, C.; Linden, G.; Hugues, M.; Lazdunski, M. Purification and pharmacological properties of eight sea anemone toxins from Anemonia sulcata, Anthopleura xanthogrammica, Stoichactis giganteus, and Actinodendron plumosum. Biochemistry 1981, 20, 5245-5252. [CrossRef]

126. Cariello, L.; de Santis, A.; Fiore, F.; Piccoli, R.; Spagnuolo, A.; Zanetti, L.; Parente, A. Calitoxin, a neurotoxic peptide from the sea anemone Calliactis parasitica: Amino acid sequence and electrophysiological properties. Biochemistry 1989, 28, $2484-2489$. [CrossRef] [PubMed]

127. Tanaka, M.; Hainu, M.; Yasunobu, K.T.; Norton, T.R. Amino acid sequence of the Anthopleura xanthogrammica heart stimulant, anthopleurin A. Biochemistry 1977, 16, 204-208. [CrossRef] [PubMed]

128. Reimer, N.S.; Yasunobu, C.L.; Yasunobu, K.T.; Norton, T.R. Amino acid sequence of the Anthopleura xanthogrammica heart stimulant, anthopleurin-B. J. Biol. Chem. 1985, 260, 8690-8693. [CrossRef]

129. Lin, X.Y.; Ishida, M.; Nagashima, Y.; Shiomi, K. A polypeptide toxin in the sea anemone Actinia equina homologous with other sea anemone sodium channel toxins: Isolation and amino acid sequence. Toxicon 1996, 34, 57-65. [CrossRef]

130. Shiomi, K.; Lin, X.-Y.; Nagashima, Y.; Ishida, M. Isolation and Amino Acid Sequences of Polypeptide Toxins in the Caribbean Sea Anemone Condylactis passiflora. Fish. Sci. 1995, 61, 1016-1021. [CrossRef]

131. Shiomi, K.; Lin, X.-Y.; Nagashima, Y.; Ishida, M. Isolation and Amino Acid Sequence of a Polypeptide Toxin from the Sea Anemone Radianthus crispus. Fish. Sci. 1996, 62, 629-633. [CrossRef]

132. Sunahara, S.; Muramoto, K.; Tenma, K.; Kamiya, H. Amino acid sequence of two sea anemone toxins from Anthopleura fuscoviridis. Toxicon 1987, 25, 211-219. [CrossRef]

133. Malpezzi, E.L.; de Freitas, J.C.; Muramoto, K.; Kamiya, H. Characterization of peptides in sea anemone venom collected by a novel procedure. Toxicon 1993, 31, 853-864. [CrossRef]

134. Loret, E.P.; del Valle, R.M.; Mansuelle, P.; Sampieri, F.; Rochat, H. Positively charged amino acid residues located similarly in sea anemone and scorpion toxins. J. Biol. Chem. 1994, 269, 16785-16788. [CrossRef]

135. Ishida, M.; Yokoyama, A.; Shimakura, K.; Nagashima, Y.; Shiomi, K. Halcurin, a polypeptide toxin from the sea anemone Halcurias sp., with a structural resemblance to type 1 and 2 toxins. Toxicon 1997, 35, 537-544. [CrossRef]

136. Shiomi, K.; Qian, W.H.; Lin, X.Y.; Shimakura, K.; Nagashima, Y.; Ishida, M. Novel polypeptide toxins with crab lethality from the sea anemone Anemonia erythraea. Biochim. Biophys. Acta. 1997, 1335, 191-198. [CrossRef]

137. Wang, L.; Ou, J.; Peng, L.; Zhong, X.; Du, J.; Liu, Y.; Huang, Y.; Liu, W.; Zhang, Y.; Dong, M.; et al. Functional expression and characterization of four novel neurotoxins from sea anemone Anthopleura sp. Biochem. Biophys. Res. Commun. 2004, 313, 163-170. [CrossRef]

138. Widmer, H.; Wagner, G.; Schweitz, H.; Lazdunski, M.; Wüthrich, K. The secondary structure of the toxin ATX Ia from Anemonia sulcata in aqueous solution determined on the basis of complete sequence-specific 1H-NMR assignments. Eur. J. Biochem. 1988, 171, 177-192. [CrossRef] [PubMed]

139. Scheffler, J.J.; Tsugita, A.; Linden, G.; Schweitz, H.; Lazdunski, M. The amino acid sequence of toxin V from Anemonia sulcata. Biochem. Biophys. Res. Commun. 1982, 107, 272-278. [CrossRef]

140. Kelso, G.J.; Blumenthal, K.M. Identification and characterization of novel sodium channel toxins from the sea anemone Anthopleura xanthogrammica. Toxicon 1998, 36, 41-51. [CrossRef]

141. Norton, T.R. Cardiotonic polypeptides from Anthopleura xanthogrammica (Brandt) and A. elegantissima (Brandt). Fed. Proc. 1981, 40, 21-25. 
142. Bruhn, T.; Schaller, C.; Schulze, C.; Sanchez-Rodriguez, J.; Dannmeier, C.; Ravens, U.; Heubach, J.F.; Eckhardt, K.; Schmidtmayer, J.; Schmidt, H.; et al. Isolation and characterisation of five neurotoxic and cardiotoxic polypeptides from the sea anemone Anthopleura elegantissima. Toxicon 2001, 39, 693-702. [CrossRef]

143. Cunha, R.B.; Santana, A.N.C.; Amaral, P.C.; Carvalho, M.D.F.; Carvalho, D.M.F.; Cavalheiro, E.A.; Maigret, B.; Ricart, C.A.; Cardi, B.A.; Sousa, M.V.; et al. Primary structure, behavioral and electroencephalographic effects of an epileptogenic peptide from the sea anemone Bunodosoma cangicum. Toxicon 2005, 45, 207-217. [CrossRef] [PubMed]

144. Honma, T.; Hasegawa, Y.; Ishida, M.; Nagai, H.; Nagashima, Y.; Shiomi, K. Isolation and molecular cloning of novel peptide toxins from the sea anemone Antheopsis maculata. Toxicon 2005, 45, 33-41. [CrossRef]

145. Shiomi, K.; Honma, T.; Ide, M.; Nagashima, Y.; Ishida, M.; Chino, M. An epidermal growth factor-like toxin and two sodium channel toxins from the sea anemone Stichodactyla gigantea. Toxicon 2003, 41, 229-236. [CrossRef]

146. Zykova, T.A.; Kozlovskaia, E.P. [Amino acid sequence of a neurotoxin from the anemone Radianthus macrodactylus]. Bioorg. Khim. 1989, 15, 1301-1306. [PubMed]

147. Zykova, T.A.; Kozlovskaia, E.P.; Eliakov, G.B. [Amino acid sequence of neurotoxin II from the sea anemone Radianthus macrodactylus]. Bioorg. Khim. 1988, 14, 878-882. [PubMed]

148. Zykova, T.A.; Kozlovskaia, E.P.; Eliakov, G.B. [Amino acid sequence of neurotoxins IV and V from the sea anemone Radianthus macrodactylus]. Bioorg. Khim. 1988, 14, 1489-1494.

149. Metrione, R.M.; Schweitz, H.; Walsh, K.A. The amino acid sequence of toxin RpIII from the sea anemone, Radianthus paumotensis. FEBS Lett. 1987, 218, 59-62. [CrossRef]

150. Kem, W.R.; Parten, B.; Pennington, M.W.; Price, D.A.; Dunn, B.M. Isolation, characterization, and amino acid sequence of a polypeptide neurotoxin occurring in the sea anemone Stichodactyla helianthus. Biochemistry 1989, 28, 3483-3489. [CrossRef]

151. Madio, B.; King, G.F.; Undheim, E.A.B. Sea Anemone Toxins: A Structural Overview. Mar. Drugs 2019, 17, 325. [CrossRef]

152. Prashanth, J.R.; Dutertre, S.; Jin, A.H.; Lavergne, V.; Hamilton, B.; Cardoso, F.C.; Griffin, J.; Venter, D.J.; Alewood, P.F.; Lewis, R.J. The role of defensive ecological interactions in the evolution of conotoxins. Mol. Ecol. 2016, 25, 598-615. [CrossRef]

153. Kumar, P.S.; Kumar, D.S.; Umamaheswari, S. A perspective on toxicology of Conus venom peptides. Asian Pac. J. Trop. Med. 2015, 8, 337-351. [CrossRef]

154. Kapil, S.; Hendriksen, S.; Cooper, J.S. Cone Snail Toxicity; StatPearls Publishing: Treasure Island, FL, USA, 2021. Available online: http:/ / www.ncbi.nlm.nih.gov/books/NBK470586/ (accessed on 25 July 2021).

155. Dutertre, S.; Jin, A.-H.; Vetter, I.; Hamilton, B.; Sunagar, K.; Lavergne, V.; Dutertre, V.; Fry, B.G.; Antunes, A.; Venter, D.J.; et al. Evolution of separate predation- and defence-evoked venoms in carnivorous cone snails. Nat. Commun. 2014, 5, 3521. [CrossRef] [PubMed]

156. Olivera, B.M. Conus Venom Peptides: Reflections from the Biology of Clades and Species. Annu. Rev. Ecol. Syst. 2002, 33, 25-47. [CrossRef]

157. Terlau, H.; Olivera, B.M. Conus venoms: A rich source of novel ion channel-targeted peptides. Physiol Rev. 2004, 84, 41-68. [CrossRef] [PubMed]

158. Gao, B.; Peng, C.; Yang, C.; Yi, Y.; Zhang, J.; Shi, Q. Cone Snails: A Big Store of Conotoxins for Novel Drug Discovery. Toxins 2017, 9, 397. [CrossRef]

159. Hui, K.; Lipkind, G.; Fozzard, H.A.; French, R.J. Electrostatic and Steric Contributions to Block of the Skeletal Muscle Sodium Channel by $\mu$-Conotoxin. J. Gen. Physiol. 2002, 119, 45-54. [CrossRef]

160. Leipold, E.; DeBie, H.; Zorn, S.; Adolfo, B.; Olivera, B.M.; Terlau, H.; Heinemann, S.H. $\mu$ O-Conotoxins Inhibit NaV Channels by Interfering with their Voltage Sensors in Domain-2. Channels 2007, 1, 253-262. [CrossRef]

161. Leipold, E.; Hansel, A.; Olivera, B.M.; Terlau, H.; Heinemann, S.H. Molecular interaction of delta-conotoxins with voltage-gated sodium channels. FEBS Lett. 2005, 579, 3881-3884. [CrossRef]

162. Wang, L.; Liu, J.; Pi, C.; Zeng, X.; Zhou, M.; Jiang, X.; Chen, S.; Ren, Z.; Xu, A. Identification of a novel M-superfamily conotoxin with the ability to enhance tetrodotoxin sensitive sodium currents. Arch. Toxicol. 2009, 83, 925-932. [CrossRef]

163. Ekberg, J.; Jayamanne, A.; Vaughan, C.W.; Aslan, S.; Thomas, L.; Mould, J.; Drinkwater, R.; Baker, M.D.; Abrahamsen, B.; Wood, J.N.; et al. $\mu \mathrm{O}$-conotoxin MrVIB selectively blocks Nav1.8 sensory neuron specific sodium channels and chronic pain behavior without motor deficits. Proc. Natl. Acad. Sci. USA 2006, 103, 17030-17035. [CrossRef]

164. Ekberg, J.; Craik, D.J.; Adams, D.J. Conotoxin modulation of voltage-gated sodium channels. Int. J. Biochem. Cell Biol. 2008, 40, 2363-2368. [CrossRef] [PubMed]

165. Stürzebecher, A.S.; Hu, J.; Smith, E.S.J.; Frahm, S.; Santos-Torres, J.; Kampfrath, B.; Auer, S.; Lewin, G.R.; Ibañez-Tallon, I. An in vivo tethered toxin approach for the cell-autonomous inactivation of voltage-gated sodium channel currents in nociceptors. J. Physiol. 2010, 588, 1695-1707. [CrossRef] [PubMed]

166. Dib-Hajj, S.D.; Tyrrell, L.; Black, J.A.; Waxman, S.G. NaN, a novel voltage-gated Na channel, is expressed preferentially in peripheral sensory neurons and down-regulated after axotomy. Proc. Natl. Acad. Sci. USA 1998, 95, 8963-8968. [CrossRef] [PubMed]

167. Zorn, S.; Leipold, E.; Hansel, A.; Bulaj, G.; Olivera, B.M.; Terlau, H.; Heinemann, S.H. The $\mu$ O-conotoxin MrVIA inhibits voltage-gated sodium channels by associating with domain-3. FEBS Lett. 2006, 580, 1360-1364. [CrossRef]

168. Knapp, O.; Nevin, S.; Yasuda, T.; Lawrence, N.; Lewis, R.; Adams, D. Biophysical properties of Nav1.8/Nav1.2 chimeras and inhibition by $\mu \mathrm{O}$-conotoxin MrVIB. Br. J. Pharmacol. 2012, 166, 2148-2160. [CrossRef] [PubMed] 
169. Vetter, I.; Dekan, Z.; Knapp, O.; Adams, D.J.; Alewood, P.F.; Lewis, R.J. Isolation, characterization and total regioselective synthesis of the novel $\mu \mathrm{O}$-conotoxin MfVIA from Conus magnificus that targets voltage-gated sodium channels. Biochem. Pharmacol. 2012, 84, 540-548. [CrossRef] [PubMed]

170. Pi, C.; Liu, J.; Wang, L.; Jiang, X.; Liu, Y.; Peng, C.; Chen, S.; Xu, A. Soluble expression, purification and functional identification of a disulfide-rich conotoxin derived from Conus litteratus. J. Biotechnol. 2007, 128, 184-193. [CrossRef]

171. Craik, D.J.; Daly, N.L.; Waine, C. The cystine knot motif in toxins and implications for drug design. Toxicon 2001, $39,43-60$. [CrossRef]

172. Wakamatsu, K.; Kohda, D.; Hatanaka, H.; Lancelin, J.M.; Ishida, Y.; Oya, M.; Nakamura, H.; Inagaki, F.; Sato, K. Structure-activity relationships of mu-conotoxin GIIIA: Structure determination of active and inactive sodium channel blocker peptides by NMR and simulated annealing calculations. Biochemistry 1992, 31, 12577-12584. [CrossRef]

173. McArthur, J.R.; Singh, G.; McMaster, D.; Winkfein, R.; Tieleman, D.P.; French, R.J. Interactions of key charged residues contributing to selective block of neuronal sodium channels by $\mu$-conotoxin KIIIA. Mol. Pharmacol. 2011, 80, 573-584. [CrossRef]

174. Shon, K.-J.; Olivera, B.M.; Watkins, M.; Jacobsen, R.B.; Gray, W.R.; Floresca, C.Z.; Cruz, L.J.; Hillyard, D.R.; Brink, A.; Terlau, H.; et al. $\mu$-Conotoxin PIIIA, a New Peptide for Discriminating among Tetrodotoxin-Sensitive Na Channel Subtypes. J. Neurosci. 1998, 18, 4473-4481. [CrossRef]

175. Zhang, M.-M.; Green, B.R.; Catlin, P.; Fiedler, B.; Azam, L.; Chadwick, A.; Terlau, H.; McArthur, J.R.; French, R.J.; Gulyas, J.; et al. Structure/function characterization of micro-conotoxin KIIIA, an analgesic, nearly irreversible blocker of mammalian neuronal sodium channels. J. Biol. Chem. 2007, 282, 30699-30706. [CrossRef] [PubMed]

176. Leipold, E.; Markgraf, R.; Miloslavina, A.; Kijas, M.; Schirmeyer, J.; Imhof, D.; Heinemann, S.H. Molecular determinants for the subtype specificity of $\mu$-conotoxin SIIIA targeting neuronal voltage-gated sodium channels. Neuropharmacology 2011, 61, 105-111. [CrossRef] [PubMed]

177. McArthur, J.R.; Ostroumov, V.; Al-Sabi, A.; McMaster, D.; French, R.J. Multiple, distributed interactions of $\mu$-conotoxin PIIIA associated with broad targeting among voltage-gated sodium channels. Biochemistry 2011, 50, 116-124. [CrossRef]

178. Nielsen, C.K.; Lewis, R.J.; Alewood, D.; Drinkwater, R.; Palant, E.; Patterson, M.; Yaksh, T.L.; McCumber, D.; Smith, M.T. Anti-allodynic efficacy of the $\chi$-conopeptide, Xen2174, in rats with neuropathic pain. Pain 2005, 118, 112-124. [CrossRef] [PubMed]

179. Malmberg, A.B.; Gilbert, H.; McCabe, R.T.; Basbaum, A.I. Powerful antinociceptive effects of the cone snail venom-derived subtype-selective NMDA receptor antagonists conantokins G and T. Pain 2003, 101, 109-116. [CrossRef]

180. Craig, A.G.; Norberg, T.; Griffin, D.; Hoeger, C.; Akhtar, M.; Schmidt, K.; Low, W.; Dykert, J.; Richelson, E.; Navarro, V.; et al. Contulakin-G, an O-glycosylated invertebrate neurotensin. J. Biol. Chem. 1999, 274, 13752-13759. [CrossRef]

181. Vetter, I.; Lewis, R.J. Therapeutic potential of cone snail venom peptides (conopeptides). Curr. Top. Med. Chem. 2012, 12, 1546-1552. [CrossRef]

182. Knapp, O.; McArthur, J.R.; Adams, D.J. Conotoxins Targeting Neuronal Voltage-Gated Sodium Channel Subtypes: Potential Analgesics? Toxins 2012, 4, 1236-1260. [CrossRef]

183. Goodwin, G.; McMahon, S.B. The physiological function of different voltage-gated sodium channels in pain. Nat. Rev. Neurosci. 2021, 22, 263-274. [CrossRef]

184. Schwartz, D.M.; Fields, H.L. Method of Local Anesthesia. WO1998043619A3, 1998. Available online: https:/ / patents.google. $\mathrm{com} /$ patent/WO1998043619A3/en?oq=tetrodotoxin (accessed on 30 December 1998).

185. Dong, Q.; Shum, F.H. A Method of Analgesia. EP2298306A1, 2011. Available online: https://patents.google.com/patent/EP229 8306A1/en?oq=tetrodotoxin (accessed on 23 March 2011).

186. Buschmann, H.; Hamon, M.; Shum, F.H.K.; Fisher, K.N.; Ngoc, A.H. Tetrodotoxin and Its Derivatives for the Treatment of Central-Nervously Derived Neuropathic Pain. CA2581128A1, 2006. Available online: https://patents.google.com/patent/CA2 581128A1/en?oq=tetrodotoxin (accessed on 30 March 2006).

187. Buschmann, H.H.; Gomis, A.F.; Hamon, M. Analgesic Combination of Sodium Channel Blockers with Opioid Antagonists. WO2006097358A2, 2006. Available online: https://patents.google.com/patent/WO2006097358A2/en?oq=tetrodotoxin (accessed on 21 September 2006).

188. Buschmann, H.H.; Hernandez, J.M.V.; Baeyens, J.M. Use of Sodium Channel Blockers for the Treatment of Neuropathic Pain Developing as a Consequence of Chemotherapy. US9018222B2, 2015. Available online: https://patents.google.com/patent/US9 018222/en?oq=tetrodotoxin (accessed on 28 April 2015).

189. Buschmann, H.H.; Hernández, J.M.V.; Candenas, L. Use of Sodium Channel Blockers for the Treatment of Preterm Labor [Internet]. WO2007096170A1, 2007. Available online: https://patents.google.com/patent/WO2007096170A1/en?oq=tetrodotoxin (accessed on 30 August 2007).

190. Fisher, K.N.; Ngoc, A.H.; Wang, E.R. Use of Sodium Channel Blockers for the Management of Musculoskeletal Pain. WO2007025213A2, 2007. Available online: https:// patents.google.com/patent/WO2007025213A2/en?oq=tetrodotoxin (accessed on 1 March 2007).

191. Lin, T.; Wu, B. Tetrodotoxin Film and Its Preparation Method. CN102920684B, 2014. Available online: https://patents.google. $\mathrm{com} /$ patent/CN102920684B/en?oq=tetrodotoxin (accessed on 28 May 2014). 
192. Mulcahy, J.; Pajouhesh, H.; Shibuya, G.M.; Delwig, A.; Dubois, J.; Miljanich, G. 11,13-Modified Saxitoxins for the Treatment of Pain. WO2017059385A1, 2017. Available online: https://patents.google.com/patent/WO2017059385A1/fr?oq=Saxitoxin (accessed on 6 April 2017).

193. Pajouhesh, H.; Miljanich, G.; Mulcahy, J.; Bois, J.D.; Axtman, M.; Walker, J. 10',11'-Modified Saxitoxin Useful for the Treatment of Pain. CA2944549A1, 2015. Available online: https:/ / patents.google.com/patent/CA2944549A1/en?oq=Saxitoxin (accessed on 15 October 2015).

194. Berde, C.; Kohane, D.S. Neosaxitoxin Combination Formulations for Prolonged Local Anesthesia. US8975268B2, 2015. Available online: https:/ / patents.google.com/patent/US8975268/en?oq=tetrodotoxin (accessed on 10 March 2015).

195. Hong, B.; Yi, R.; Chen, Y.; Chen, H.; Bai, K.; Sun, J. Tetrodotoxin Compound Preparation with Antiarrhythmic Effect and Preparation Method Thereof. CN105030782A, 2015. Available online: https:/ / patents.google.com/patent/CN105030782A/en? oq=tetrodotoxin (accessed on 11 November 2015).

196. Buschmann, H.H.; Gomis, A.F.; Hernández, J.M.V. Use of Sodium Channel Blockers and Their Analogues for the Treatment of Nicotine Dependency. WO2006084765A1, 2006. Available online: https://patents.google.com/patent/WO2006084765A1/en? oq=tetrodotoxin (accessed on 17 August 2006).

197. Favreau, P.; Benoit, E.; Molgo, J.; Stöcklin, R. Mu-Conotoxin Peptides and Use Thereof as a Local Anesthetic. US9644011B2, 2017. Available online: https:/ / patents.google.com/patent/US9644011/en?oq=conotoxin+pharmaceutical (accessed on 9 May 2017). 